\title{
Microalgae for High-Value Products Towards Human Health and Nutrition
}

\author{
Ines Barkia ${ }^{1}$, Nazamid Saari ${ }^{1, *(\mathbb{D})}$ and Schonna R. Manning ${ }^{2}$ \\ 1 Department of Food Science, Universiti Putra Malaysia, Selangor 43400, Malaysia; ines.barkia@gmail.com \\ 2 Department of Molecular Biosciences, UTEX Culture Collection of Algae, University of Texas at Austin, \\ Austin, TX 78712, USA; schonna.manning@utexas.edu \\ * Correspondence: nazamid@upm.edu.my
}

Received: 25 March 2019; Accepted: 2 April 2019; Published: 24 May 2019

check for updates

\begin{abstract}
Microalgae represent a potential source of renewable nutrition and there is growing interest in algae-based dietary supplements in the form of whole biomass, e.g., Chlorella and Arthrospira, or purified extracts containing omega- 3 fatty acids and carotenoids. The commercial production of bioactive compounds from microalgae is currently challenged by the biorefinery process. This review focuses on the biochemical composition of microalgae, the complexities of mass cultivation, as well as potential therapeutic applications. The advantages of open and closed growth systems are discussed, including common problems encountered with large-scale growth systems. Several methods are used for the purification and isolation of bioactive compounds, and many products from microalgae have shown potential as antioxidants and treatments for hypertension, among other health conditions. However, there are many unknown algal metabolites and potential impurities that could cause harm, so more research is needed to characterize strains of interest, improve overall operation, and generate safe, functional products.
\end{abstract}

Keywords: Microalgae; bioactive compounds; health benefits; antioxidant activity; antihypertensive activity; anti-inflammatory activity

\section{Introduction}

Algae are a complex, polyphyletic assemblage of (mostly) photosynthetic organisms. Organisms in the algae include diverse micro- and macroscopic forms that are distributed across the tree of life, including eukaryotic and prokaryotic members [1], making algae the most genetically-diverse set of organisms on the planet. While the phylogenetic relationships continue to be resolved among groups, algae can be broadly assigned to eleven major phyla: Cyanophyta, Chlorophyta, Rhodophyta, Glaucophyta, Euglenophyta, Chlorarachniophyta, Charophyta, Cryptophyta, Haptophyta, Heterokontophyta, and Dinophyta.

The major groups of eukaryotic algae arose through multiple endosymbiotic events, resulting in broadly-distributed and highly-diverse lineages. The Glaucophyta, Rhodophyta, and Chlorophyta evolved via the primary endosymbiosis of a photosynthetic cyanobacterium (Cyanophyta), which gave rise to the chloroplast. Secondary endosymbiosis of green algae led to two major groups, the Euglenophyta and photosynthetic Rhizaria, the Chlorarachniophyta [2]. Similarly, the secondary endosymbiosis of a red alga gave rise to the Cryptophyta, Heterokontophyta, Haptophyta, and Dinophyta. There are tertiary (and possibly quaternary) endosymbiotic events between the Dinophyta and Haptophyta, resulting in genomes greater than $500 \mathrm{Gbps}[3,4]$.

The pigments found in the algae are diagnostic for each major group [5]. Cyanobacteria contain chlorophyll-a, $-\mathrm{d}$, and $-\mathrm{f}$, as well as the phycobiliproteins, phycocyanin, allophycocyanin, and phycoerythrin. Glaucophytes contain chlorophyll-a and harvest light via phycobiliproteins. 
The Chlorophyta contain chlorophyll-a and $-\mathrm{b}$, as well as a suite of carotenoids, including $\beta$-carotene and various xanthophylls (e.g., astaxanthin, canthaxanthin, lutein, zeaxanthin, etc.). The primary pigments of the Rhodophyte algae are phycoerythrin and phycocyanin, which can mask chlorophyll-a. There are no accessory chlorophylls; although, red algae do produce a broad spectrum of carotenes and xanthophyll light-harvesting pigments.

Cyanobacteria and eukaryotic microalgae also synthesize numerous secondary metabolites, including potentially beneficial bioactives, such as antioxidants, as well as many compounds that are broadly characterized as toxins. These bioactive compounds are produced via the shikimic acid, mevalonic/non-mevalonic acid, and acetate pathways, e.g., anatoxins, brevetoxins, cylindrospermopsin, microcystins, and prymnesins, among many more (see [6]). There are greater than 200 bioactive metabolites predicted from cyanobacteria [7], and thousands more are predicted from eukaryotic microalgae. However, there are very few assays or reference standards available for the detection of microalgal metabolites, indicating a major gap and a need for more research in this area. Examples of microalgal pigments and bioactive compounds discussed in this review are illustrated in Figure 1.

(a)

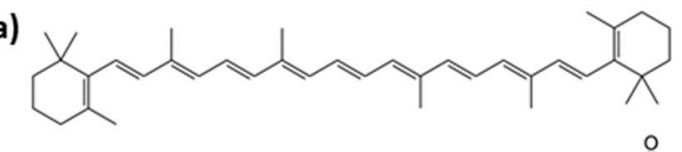

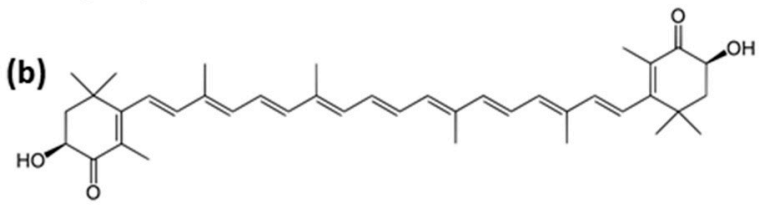

(c)

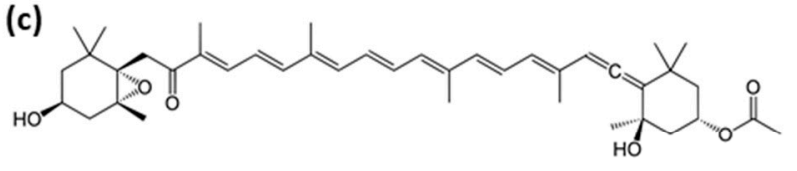

(g)

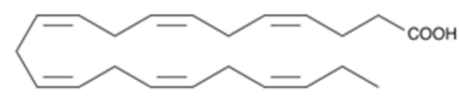

(h)

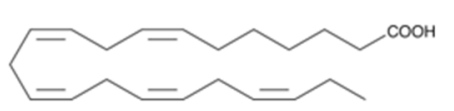

(i)

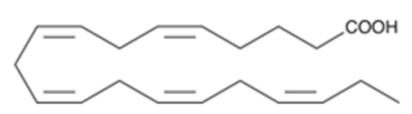

(d)

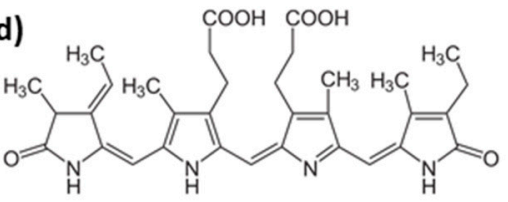

(e)<smiles></smiles>

(f)
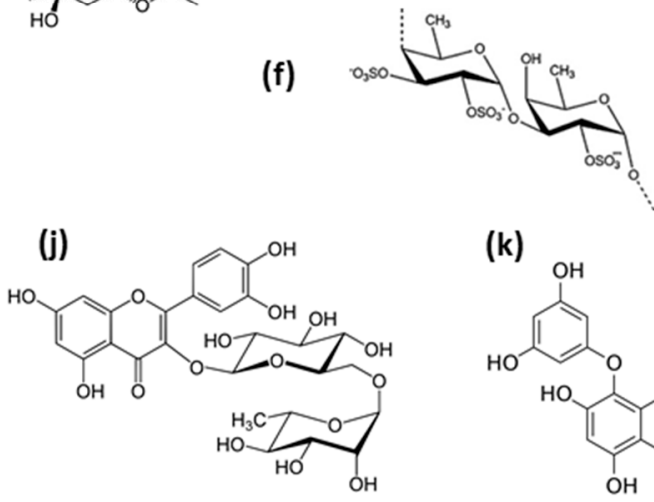

(k)

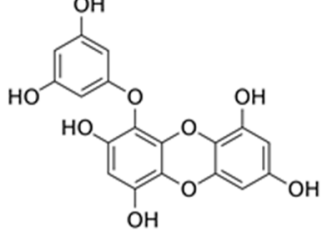

Figure 1. Bioactive compounds from microalgae include: carotenoids, $\beta$-carotene (a). astaxanthin (b), and fucoxanthin (c); phycobilins, phycocyanin (d) and phycoerythrin (e); sulfated polysaccharides (f); omega-3 fatty acids, docosahexaenoic acid (g), docosapentaenoic acid (h), and eicosapentaenoic acid (i); and phenolics, rutin (j) and eckol (k).

Microalgae are presented as new model organisms for a wide range of biotechnological applications, including biodiesel production [8], wastewater bioremediation [9], and dietary supplements for animal and human nutrition [10-12]. Recent economic viability studies have shown that, due to limited biomass productivity and the costs of commercial algal production, the production of biofuels is not cost-effective unless the process is coupled with the commercialization of higher-value co-products [13]. By comparison, the use of microalgae biomass for the development of products with health benefits, such as nutraceuticals and functional foods, is a rapidly growing market [14]. For example, the worldwide carotenoid market is expected to increase from \$1.24 billion USD in 2016 to more than $\$ 1.53$ billion USD by 2021 [15]. 
A lot of funding has been invested over the last few decades to screen microalgal bioactive metabolites [16]. Several bioactive compounds have been discovered and purified from marine microalgae, including sulfated polysaccharides [17], marennine [18], various carotenoids (e.g., astaxanthin, fucoxanthin, $\beta$-carotene [19,20]), omega-3 fatty acids [21], and polyphenols [22]. Some of these metabolites have demonstrated biological activities, including potent antioxidant, anti-inflammatory, anticancer, and antiviral properties [23-25]. Thus, microalgae and microalgae-derived compounds have great potential as supplements in the human diet for the prevention, management, and treatment of physiological aberrations, in addition to providing sustainable natural resources in lieu of synthetic dietary supplements [26]. However, there are emergent biological and economic challenges associated with the large-scale cultivation of microalgae and the biorefinery process that must be addressed to ensure the sustainable production of high-value products with nutritional and health benefits.

\section{Microalgae-Based Functional Foods}

The use of "wild" harvested macroalgae for food purposes has been well established for hundreds of years in Asiatic countries. Nevertheless, the commercial cultivation of microalgae for biomass started only 60 years ago, e.g., Chlorella vulgaris was produced in Japan and Taiwan in the 1960s, and the mass production of Arthrospira (formerly known as Spirulina), Dunaliella salina, and the cultivation of Haematococcus pluvialis was developed in the USA, Israel, Australia, China, and Thailand in the 1980s [27]. The market for dietary supplements in the form of dried biomass is presently dominated by Arthrospira and Chlorella (Table 1).

Table 1. Major microalgal products and producers for human nutrition (adapted from [12,28]).

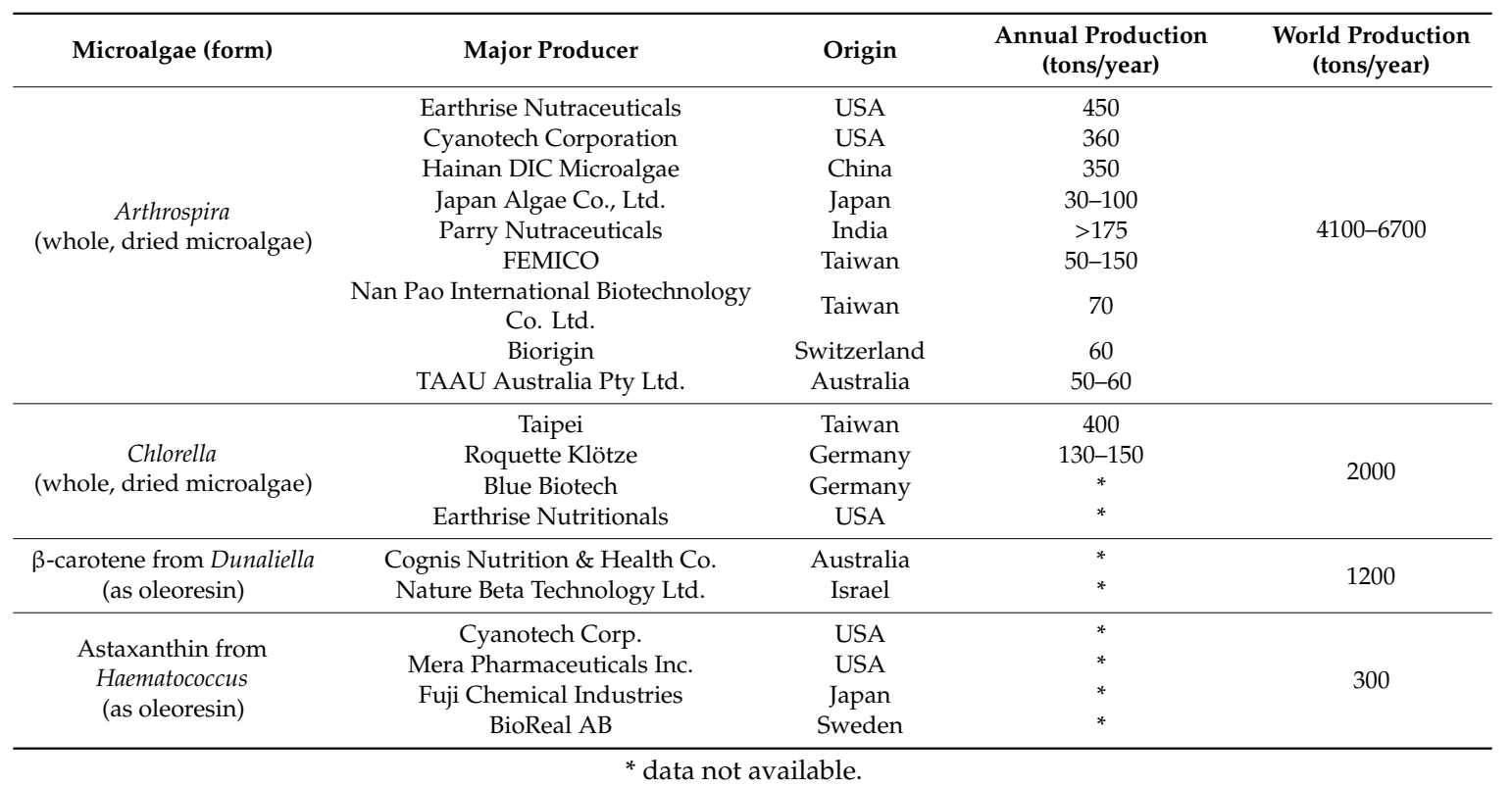

Interest in whole-biomass products, commercially known as "super foods", are attributed to reports of high protein content, nutritive value, and health benefits [29]. Arthrospira is marketed as a source of high-quality protein, $\gamma$-linolenic acid, and phycocyanin content. Arthrospira is also reported to exhibit antiviral, anticancer, antioxidant, and anti-inflammatory properties among other effects [30-32]. Green algae in the genus Chlorella have been advertised as providing a "growth factor", which is a water-soluble extract composed of a variety of substances, including nucleic acids, amino acids, vitamins, minerals, polysaccharides, glycoproteins, and $\beta$-glucans [33]. Extracts from Chlorella have demonstrated many beneficial properties, such as lowering cholesterol as well as antioxidant, antibacterial, and antitumor activities [34-36]. 
Despite the reported benefits, there are also numerous studies indicating that the ingestion of high amounts of Chlorella or Arthrospira may result in severe side effects. For example, the excessive intake of Chlorella was documented as causing allergies, nausea, vomiting, and other gastrointestinal problems [37]. Some of these effects were reported with the 2016 recall of Soylent products that contained Chlorella algal flour as an ingredient. In other cases, Chlorella was found to induce acute tubulointerstitial nephritis, which can cause renal failure [38]. With excessive ingestion of Arthrospira, possible side effects included diarrhea, nausea, and vomiting [39]. The reported bioavailability of vitamin $B_{12}$ has also been riddled with controversy, which makes it an unreliable supplement for treating $B_{12}$ deficiency [40]. Moreover, Gilroy et al. reported that under certain uncontrolled cultivation conditions, Arthrospira biomass may contain significant amounts of heavy metals (e.g., mercury, cadmium, arsenic, and lead) or toxins, like microcystins, from co-occurring cyanobacteria, wherein prolonged consumption of Arthrospira tablets could cause irreversible damage to visceral organs, such as the kidneys and the liver [41].

The potentially serious side effects of commercially-accepted microalgae, like Chlorella and Arthrospira, have raised serious doubts about the suitability of other strains of microalgae for human consumption [42]. Moreover, there are many more bioactive compounds yet to be discovered. Thus, there is an immediate need to detect potentially harmful metabolites, as well as to develop methods to extract targeted compounds from microalgae instead of using the whole biomass.

\section{Biochemical Composition of Microalgae}

Microalgae produce a suite of biochemical molecules, including carbohydrates, proteins, lipids, and nucleic acids, as well as essential vitamins and minerals. The cellular content of each fraction varies according to the specific strain of algae and their physiological responses to biotic and abiotic factors, e.g., light intensity, photoperiod, temperature, nutrients, and growth phase $[43,44]$. The primary biochemical compositions of selected species of microalgae are shown in Table 2.

Table 2. Biochemical composition of different species of microalgae.

\begin{tabular}{|c|c|c|c|c|c|}
\hline Species & Class & $\%$ Protein $(w / w)$ & $\%$ Carbs $(w / w)$ & $\%$ Fat $(w / w)$ & References \\
\hline Phaeodactylum tricornutum & Bacillariophyceae & 34.8 & 16.8 & 16.1 & {$[45,46]$} \\
\hline Nitzschia closterium & Bacillariophyceae & 26 & 9.8 & 13 & [45] \\
\hline Chlamydomonas reinhardtii & Chlorophyceae & 48 & 17 & 21 & [47] \\
\hline Dunaliella tertiolecta & Chlorophyceae & 11 & - & - & [48] \\
\hline Dunaliella primolecta & Chlorophyceae & 12 & - & - & [49] \\
\hline Dunaliella salina & Chlorophyceae & 57 & 32 & 6 & [47] \\
\hline Dunaliella sp. & Chlorophyceae & 34.17 & 14.57 & 14.36 & [50] \\
\hline Scenedesmus obliquus & Chlorophyceae & $48-56$ & $10-17$ & $12-14$ & {$[47,51]$} \\
\hline Scenedesmus sp. & Chlorophyceae & 31 & 28 & 15 & {$[50]$} \\
\hline Chaetoceros calcitrans & Coscinodiscophyceae & 34 & 6.0 & 16 & [45] \\
\hline Chaetoceros calcitrans & Coscinodiscophyceae & 40 & 37 & 23 & [52] \\
\hline Chaetoceros gracilis & Coscinodiscophyceae & 12 & 4.7 & 7.2 & {$[45]$} \\
\hline Chaetoceros muelleri & Coscinodiscophyceae & 59 & 10 & 31 & [52] \\
\hline Skeletonema costatum & Coscinodiscophyceae & 25 & 4.6 & 10 & {$[45]$} \\
\hline Thalassiosira pseudonana & Coscinodiscophyceae & 34 & 8.8 & 19 & {$[45]$} \\
\hline Spirulina maxima & Cyanophyceae & $60-71$ & $13-16$ & $6-7$ & [47] \\
\hline Synechococcus sp. & Cyanophyceae & 63 & 15 & 11 & [47] \\
\hline Nannochloropsis sp. & Eustigmatophyceae & 30 & 10 & 22 & [50] \\
\hline Nannochloropsis granulata & Eustigmatophyceae & $18-34$ & $27-36$ & $24-28$ & [46] \\
\hline Pavlova sp. & Pavlovophyceae & $24-29$ & $6-9$ & $9-14$ & {$[45,47]$} \\
\hline Porphyridium cruentum & Porphyridiophyceae & $28-39$ & $40-57$ & $9-14$ & [47] \\
\hline Tetraselmis chuii & Prasinophyceae & $31-46$ & 25 & 12 & {$[45,46]$} \\
\hline Tetraselmis sp. & Prasinophyceae & 36 & 24 & - & {$[53]$} \\
\hline Prymnesium sp. & Prymnesiophyceae & $28-45$ & $25-33$ & $22-38$ & [54] \\
\hline Isochrysis galbana & Prymnesiophyceae & 27 & 34 & 11 & [55] \\
\hline Schizochytrium sp. & Thraustochytriaceae & - & - & $50-77$ & [56] \\
\hline Botryococcus braunii & Trebouxiophyceae & $39-40$ & $19-31$ & $25-34$ & [46] \\
\hline Chlorella pyrenoidosa & Trebouxiophyceae & 57 & 26 & 2 & [56] \\
\hline Chlorella vulgaris & Trebouxiophyceae & $51-58$ & $12-17$ & $14-22$ & [47] \\
\hline
\end{tabular}




\subsection{Proteins}

Proteins play an important role in the structure and metabolism of microalgal cells. They are an integral component of the membrane and light-harvesting complex, including numerous catalytic enzymes involved in photosynthesis [57]. The protein content of many microalgal species can compete, quantitatively and qualitatively, with conventional protein sources $[58,59]$. In terms of quantity, several species of microalgae are reported to possess very high concentrations of protein; this can range from $42 \%$ to over $70 \%$ in certain cyanobacteria $[60,61]$ and up to $58 \%$ for Chlorella vulgaris on a dry weight basis [47]. In terms of quality, microalgae contain all of the essential amino acids that mammals are unable to synthesize. Moreover, the amino acid profiles are well-balanced and similar to high-quality protein sources, such as lactoglobulin, egg albumin, and soy [57]. The application of microalgal proteins has been limited in foods thus far. This is mainly due to the presence of non-protein components (e.g., chlorophyll) that can affect the color and taste of the microalgae-based products [47]. Moreover, the rigid cell wall of some strains, mainly green microalgae (e.g., Chlorella and Tetraselmis), can lower the extraction efficiency of intracellular proteins and whole biomass applications can result in low digestibility in humans (see later) $[47,62]$.

\subsection{Carbohydrates}

Carbohydrates, including mono-, oligo-, and polysaccharides, have both structural and metabolic functions. Carbohydrates can be found attached to proteins or lipids (e.g., glycoproteins and glycolipids), and complex polysaccharides compose the major structural features of the cell wall [63]. In addition, microalgae make glucose and starch-like energy storage products, which are the primary carbon-containing products from photosynthesis [57].

Polysaccharides are produced in a variety of forms according to the group of microalgae. Cyanophytes are known to accumulate glycogen, although some species synthesize semi-amylopectin [64]. The Chlorophyta synthesize starch in the form of two glucose polymers, amylopectin and amylose [65], while Rhodophyta produce a carbohydrate polymer known as floridean starch [66]. Diatoms (Bacillariophycae, Heterokontophyta) produce chrysolaminarin, a linear polymer of $\beta(1,3)$ and $\beta(1,6)$ linked glucose units [67]. Some diatoms can store up to $30 \%$ of their dry weight as $(1,3)-\beta$-D-glucan during the exponential growth phase and cells can accumulate up to $80 \%$ under strong nutrient limitations [68]. Similarly, a strain of Tetraselmis suecica was reported to accumulate between $11 \%$ and $47 \%$ of its dry weight as starch in nutrient replete vs deplete conditions, respectively [69].

While microalgae represent a source of beneficial carbohydrates, their use in food applications has been very limited. Instead, microalgal polysaccharides are gaining more importance in the cosmetic industry as hygroscopic agents and antioxidants for topical applications, including lotions and creams [17].

\subsection{Lipids}

Among the chemical components, lipids have received the greatest attention for extraction and commercialization. When research on algal lipids first began, the primary goal was the production of biodiesel. However, polyunsaturated fatty acids, i.e., omega fatty acids, have considerably more commercial value as nutraceuticals and in infant formulations [70].

Lipids provide the structural components of plasma membranes and neutral lipid bodies function as energy reservoirs secondary to polysaccharide stores. The lipid fraction of microalgae is mainly composed of (i) neutral lipids that include acylglycerols, free fatty acids, and carotenoids (e.g., $\beta$-carotene), and (ii) polar lipids, such as various phospholipids and galactolipids. Generally speaking, most microalgae are rich in polar lipids in the exponential phase of growth, and they accumulate triacylglycerols under stress conditions, which is typically during the stationary phase when nutrients are limited [71,72]. The fatty acid profile of microalgae is generally characterized by a mixture of C16 and C18 saturated and unsaturated fatty acids as well as longer carbon-chain lengths, including 
many omega fatty acids. Saturated fats are usually stored in neutral lipid bodies, whereas unsaturated fatty acids are mostly associated with polar lipids in the various membranes that serve to maintain membrane fluidity under varying cultivation conditions [57].

The lipid content of many microalgal species is well documented, and this fraction can represent anywhere from $20 \%$ to $50 \%$ of the dry biomass $(\mathrm{w} / \mathrm{w})$. However, other values ranging from $1 \%$ to $70 \%$ have also been reported [12]. The production of lipids depends on the microalgal species, and the synthesis of different types of lipids is greatly affected by cultivation conditions, i.e., growth phase, nutrient availability, salinity, light intensity, temperature, and $\mathrm{pH}[73,74]$. It is well known that the intracellular lipid content increases significantly during nitrogen limitation, and cultures in the stationary phase have been shown to double their neutral lipid content and synthesize polysaccharides at the expense of proteins [44,75].

\subsection{High-Value Natural Products}

Many natural products from microalgae have attracted special attention due to their broad spectrum of biological activities. According to the review of [76], more than 4000 studies on bioactive compounds from microalgae were published in the years between 1926 and 2016. From an industrial perspective, these types of products have much higher economic value than whole, dried microalgal biomass even if their production volumes are smaller (Table 3).

Table 3. Market value of selected high-value products isolated from microalgae compared to whole biomass.

\begin{tabular}{ccc}
\hline Product & Price (USD kg $\mathbf{~}^{\mathbf{- 1}}$ ) & References \\
\hline Astaxanthin & $2500-7000$ & {$[77]$} \\
$\beta$-carotene & $300-1500$ & {$[14]$} \\
Omega-3 fatty acids & $80-160$ & {$[14]$} \\
Chlorella biomass & 44 & {$[78]$} \\
Arthrospira biomass & $42 *$ & {$[79]$} \\
* Value expressed in $€$ by the authors; the value shown was converted to USD $(\$ 1.17 \mathrm{USD} / €)$.
\end{tabular}

The most popular microalgal products on the market are pigments and fatty acids [80]. More than 1200 tons of $\beta$-carotene were produced in 2010 [10]; this pigment is extracted from Dunaliella salina, a green alga that grows in open ponds under high salinity and light conditions [81]. Another commercially-important carotenoid, astaxanthin, is synthesized by the freshwater green alga, Haematococcus pluvialis [82]. While there is currently less production of astaxanthin than $\beta$-carotene, it has a higher market value [77]. However, the commercialization of astaxanthin has been slower because of the higher production costs and the absence of a pre-established market as a nutraceutical for human use [14].

Polyunsaturated fatty acids (PUFAs) from microalgae are also considered among the major commercial high-value products with an estimated market value of $\$ 140 \mathrm{USD} / \mathrm{kg}$ [14]. The interest in fatty acids from microalgae is mainly attributed to their lower levels of contamination (e.g., methyl mercury, dioxins, and polychlorinated biphenyls) when compared to fish oils [83,84]. Moreover, the use of algal fatty acids has also shown beneficial effects against inflammation and a wide range of cardiovascular diseases (e.g., hypertension, cardiac arrhythmia, myocardial infarction, and thrombosis) $[85,86]$. Several species of microalgae (e.g., Cryptothecodininum cohnii and Schizochytrium limacinum) have been cultivated industrially in fermenters (i.e., heterotrophically) for the production of docosahexaenoic acid (DHA) [70,87]. This omega-3 fatty acid is widely used as a nutritional supplement in infant formula with an estimated worldwide wholesale market of around $\$ 9.0$ billion USD/year [88]. Besides carotenoids and PUFAs, numerous high-value compounds remain to be characterized in microalgae, expanding opportunities for the discovery of new bioactive products (Table 4). 
Table 4. Bioactive compounds from microalgae and their potential health benefits.

\begin{tabular}{|c|c|c|c|}
\hline Bioactive Compounds & Source & Health Benefits & References \\
\hline \multicolumn{4}{|l|}{ Carotenoids } \\
\hline$\beta$-carotene & Dunaliella salina & $\begin{array}{l}\text { Antioxidant, pro-vitamin A, } \\
\text { anti-allergic, anti-inflammatory }\end{array}$ & {$[89,90]$} \\
\hline Astaxanthin & Haematococcus pluvialis, C. zofingiensis & Antioxidant, anti-inflammatory & [91] \\
\hline Lutein & $\begin{array}{c}\text { Scenedesmus spp., Muriellopsis sp., } \\
\text { C. sorokiniana }\end{array}$ & Antioxidant, anti-inflammatory & [92-94] \\
\hline \multicolumn{4}{|l|}{ PUFAs } \\
\hline $\begin{array}{l}\text { Arachidonic acid } \\
\text { (AA) }\end{array}$ & $\begin{array}{c}\text { Porphyridium purpureum, P. cruentum, } \\
\text { Parietochloris incisa }\end{array}$ & $\begin{array}{l}\text { Improves normal growth, visual } \\
\text { and functional development } \\
\text { in infants }\end{array}$ & [95-97] \\
\hline $\begin{array}{l}\text { Eicosapentaenoic acid } \\
\text { (EPA) }\end{array}$ & $\begin{array}{l}\text { Nannochloropsis sp., Phaeodactylum } \\
\text { tricornutum, Porphyridium cruentum }\end{array}$ & $\begin{array}{l}\text { Cardiovascular benefits, mental } \\
\text { development and support, } \\
\text { anti-inflammatory, protection } \\
\text { against atherosclerosis }\end{array}$ & [98-100] \\
\hline $\begin{array}{l}\text { Docosahexaenoic acid } \\
\text { (DHA) }\end{array}$ & $\begin{array}{l}\text { Crypthecodinium cohnii, Schizochytrium } \\
\text { spp., Ulkenia spp. }\end{array}$ & $\begin{array}{l}\text { Cardiovascular benefits, improves } \\
\text { nervous system development and } \\
\text { function of the brain }\end{array}$ & {$[101,102]$} \\
\hline \multicolumn{4}{|l|}{ Other metabolites } \\
\hline Peptides & $\begin{array}{c}\text { Chlorella pyrenoidosa, } \\
\text { Nannochloropsis oculata }\end{array}$ & $\begin{array}{l}\text { Antioxidant, anti-inflammatory, } \\
\text { anticancer, antihypertensive }\end{array}$ & {$[103,104]$} \\
\hline Phenolics & $\begin{array}{c}\text { Arthrospira maxima, Tetraselmis suecica, } \\
\text { Botryococcus braunii, } \\
\text { Isochrysis sp., Chlorella vulgaris, } \\
\text { Nannochloropsis sp. }\end{array}$ & Antioxidant & {$[22,105,106]$} \\
\hline Phycocyanin & Arthrospira platensis & Antioxidant, anti-inflammatory & [107] \\
\hline $\begin{array}{c}\text { Sulfated } \\
\text { polysaccharides }\end{array}$ & $\begin{array}{c}\text { C. pyrenoidosa, C. stigmatophora, } \\
\text { Porphyridium sp., Phaeodactylum } \\
\text { tricornutum }\end{array}$ & $\begin{array}{l}\text { antioxidant, anti-inflammatory, } \\
\text { antiviral, immunomodulatory }\end{array}$ & [108-110] \\
\hline "Water-soluble extract" & $\begin{array}{c}\text { Chlorella stigmatophora, Phaeodactylum } \\
\text { tricornutum, Graesiella sp. }\end{array}$ & $\begin{array}{l}\text { Anti-inflammatory, analgesic, } \\
\text { antioxidant, antiproliferative }\end{array}$ & {$[108,111]$} \\
\hline
\end{tabular}

\section{Microalgal Mass Cultivation}

The mass cultivation of microalgae has been evaluated for the production of sustainable biomass for food, feed, chemicals, biofuel, and high-value products [112]. Currently, there are two primary types of mass-cultivation systems: (i) Photobioreactors (PBRs), and (ii) raceway ponds. Closed PBRs offer better control over contamination and physiochemical conditions [55]. Although, the capital, operational, and energetic costs remain significantly higher than open raceway ponds, which are much less complex and require a lower capital investment [113]

While open ponds are deemed the only economically-viable cultivation system for producing lower-cost microalgal biomass, they are prone to emergent challenges, including lower productivity and biomass yields coupled with contamination [114]. As a rule, microalgae cultivated in open raceway ponds have much lower biomass productivities when compared to laboratory cultures and closed PBR systems. For example, open raceways ponds in southern Spain had biomass productivities of 27 tons $\mathrm{ha}^{-1}$ year $^{-1}$ while closed systems produced between 34-61 tons ha ${ }^{-1}$ year $^{-1}$ [115].

Some of the common stress factors that affect cellular growth and physiological performance include: contaminants and grazers; availability of nutrients and $\mathrm{CO}_{2}$ [116]; self-shading from high cell density [117]; excess accumulation of $\mathrm{O}_{2}$ during the day causing photooxidation and death [118]; and significant shifts in culture $\mathrm{pH}$ as the microalgae absorb all of the dissolved $\mathrm{CO}_{2}$ during the day and release $\mathrm{CO}_{2}$ at night [119]. To overcome the multitude of factors associated with trying to maintain mono-algal growth, extreme cultivation conditions (e.g., high salinity and alkalinity) can be applied to exclude competing organisms; however, only a limited number of microalgae are able to be cultivated under such selective conditions [120].

Paradoxically, in nature, large blooms of microalgae occur in complex environments with varying temperatures and nutrient conditions in highly-diverse biological communities. During a bloom, microalgal species temporarily outcompete others by rapidly dividing to reach dense cell concentrations, nearing the theoretical maximum level of growth rates $(\mu>1)$ [121]. While it may be advantageous to 
mimic natural conditions and grow several strains of microalgae together (polyculture), commercial growth schemes have generally focused on the cultivation of one strain, unialgal monoculture [122].

In an attempt to replicate natural bloom conditions, an efficient solution was suggested by Jovine [123] that consisted of cultivating microalgae in connected raceway ponds of increasing dimensions using reduced amounts of nutrients and without $\mathrm{CO}_{2}$ addition. The transfer from one pond to another was accompanied by diluting cultures with fresh medium at a dilution rate of at least two. Dilution improved the light availability in the raceway ponds and thus enhanced photosynthetic efficiency [70]. However, the dilution rate should always remain below the maximum specific growth rate of microalgae $\left(\mu_{\max }\right)$ in order to prevent "washout" of the cells [70]. Light and temperature also play significant roles in the growth rates of outdoor pond cultures [124,125].

It was proposed that feeding and harvesting of microalgae should be performed only during the day to prevent the loss of biomass at night due to oxidative respiration. Using a model developed by Huesemann et al. [126], researchers can now use this tool to predict biomass productivity in outdoor ponds under nutrient-replete conditions, diurnally-fluctuating light intensities, and temperature. The model has been validated for three different species of microalgae (Chlorella sorokiniana, Nannochloropsis salina, Picochlorum sp.), but hypothetically, it can be used to predict the biomass concentration of any new strain. The inputs required are strain-specific parameters (i.e., growth rate, $\mu)$, biomass loss rate in the dark $\left(\mu_{\text {dark }}\right)$, scatter-corrected biomass light absorption coefficient $\left(k_{\text {sca }}\right)$, as well as the sunlight and water temperature data. The application of this model can greatly reduce the requirement for outdoor pond tests, which represents a major bottleneck in the industrial-scale production of microalgal biomass.

\section{Purification of Bioactive Compounds from Microalgae}

\subsection{Lipids}

Various extraction and purification methods are used to recover targeted bioactive compounds from microalgal biomass. The extraction of carotenoids, including carotenes and xanthophylls, typically involves biomass pretreatment steps (e.g., acid-base treatment, enzyme lysis, mechanical disruption) to breakdown the cell wall and membranes [127]. Subsequently, carotenoids are separated from the solid biomass using traditional solvent-based extraction techniques $[128,129]$ or more environmentally-friendly alternatives, such as supercritical fluid extraction, microwave-assisted extraction, ultrasound-assisted extraction, or enzyme-assisted extraction (for more details, see the review from Ventura et al. [130]). Finally, depending on the intended applications, additional purification steps (e.g., preparative chromatography) may be needed to concentrate and purify targeted fractions and remove contaminating residues.

Similar to carotenoids, the extraction of PUFAs requires a cell disruption treatment to maximize oil recovery $[128,131]$. The extraction of lipids from microalgal cells is typically performed using non-polar organic solvents or solvent mixtures, such as chloroform-methanol and hexane-isopropanol [42,132, 133]. Following extraction, additional processing steps, including fractional distillation or winterization, are used to separate PUFAs from the total lipids. However, this fraction is still not suitable for human consumption due to the presence of impurities, odor, taste, and cloudy appearance. Thus, further purification, i.e., filtration, bleaching, deodorization, polishing, and antioxidant addition, is needed to enhance the quality and shelf-life of PUFAs $[134,135]$. It is important to note that the use of large amounts of solvents for the extraction process has raised serious concerns about health, safety, and the environment [136]. Therefore, more efforts are needed in the areas of solvent recycling, replacing traditional organic solvents with green solvents, and the implementation of more sustainable processes.

\subsection{Polysaccharides}

The extraction of polysaccharides is commonly performed using hot water [137]. This method has the advantage of simplicity and ease of scalability, but it is also time-consuming and has a low extraction 
efficiency [138]. Therefore, several novel extraction techniques have been applied to increase the yield of polysaccharides from cell culture. Among these novel techniques, microwave-, ultrasonic-, and enzyme-assisted extractions have recently gained increasing popularity. Microwave-assisted extraction was reported to have a shorter extraction time and higher extraction efficiency when compared to the conventional method [139]. However, this process can induce considerable changes in the chemical structure of polysaccharides and it has been shown to decrease the viscosity of starch solutions [140]. Ultrasonic-assisted extraction is another advanced method with higher extraction efficiency than the conventional hot water extraction [141]. Unlike microwave-assisted extraction, ultrasound-assisted extraction did not significantly change the structure or molecular weight of polysaccharides, such as alginates and carrageenans [142].

Following the extraction of polysaccharides, some purification steps are usually required to remove interfering substances, such as low molecular weight compounds, lipids, and colored algal compounds. The purification procedures may also include the use of solvents, e.g., a mixture of methanol/chloroform/water (4:2:1; v/v/v) [143], or the use of physical approaches, such as membrane separation, ion-exchange, size-exclusion, and affinity chromatographic methods (for a review, see Xu et al. [138]).

\subsection{Peptides}

Numerous methods have been utilized to generate bioactive peptides from food proteins (e.g., chemical hydrolysis, microbial fermentation, enzymatic hydrolysis). While fermentation systems are relatively low cost and easily scalable, this process has the disadvantage of low product yields because the microorganisms used for hydrolysis can also consume the released peptides or amino acids as substrate for their own growth [144]. On the other hand, chemical hydrolysis is difficult to control since its uses strong chemical reagents with no specificity for peptide bonds. Moreover, this process may cause irreversible damage to some amino acids [145]. Alternatively, enzymatic hydrolysis has been presented as the best option to produce bioactive peptides for human nutrition [146]. This process is much easier to control, it uses mild conditions that do not alter the structure of amino acids, and it preserves the functionality and nutritive value of the end products [147]. Furthermore, it does not require the use of large quantities of organic solvents or toxic chemicals [148].

The success of enzymatic hydrolysis relies on several parameters, such as substrate specificity and hydrolysis conditions (e.g., temperature, $\mathrm{pH}$, enzyme/substrate ratio, reaction time, etc.; see [138] for a review). Different strategies have been employed to enhance the yield of bioactive peptides from protein sources. One approach consists of the optimization of the proteolytic enzymes or the form of their use (single or in combination with other proteases) [149]. In this regard, several enzymes with well-known specificities (e.g., papain, alcalase, trypsin, $\alpha$-chymotrypsin, neutrase, pepsin) have been used to prepare peptides from microalgal biomass [150]. Other methods can be used to enhance the hydrolysis process, including the optimization of the substrate, its concentration, and the extent of its digestion. For example, thermal denaturation of the seaweed, Palmaria palmate, which is characterized by high levels of cell wall anionic polysaccharides, was reported to improve the yield of peptides by $64 \%$ to $96 \%$ [151].

The purification of bioactive peptides is necessary to enhance their concentration and bioactivity. Pre-treatment procedures are often applied to increase the extraction efficiency of bioactive peptides. These steps consist of concentrating proteins in mixtures by removing fats, carbohydrates, and other components from the biomass using ammonium sulphate (i.e., salting out) or solvent extraction [152]. Bioactive peptides can then be separated by a number of techniques according to their physicochemical parameters, e.g., size, hydrophobicity, and charge. Methods used for peptide isolation involve size-exclusion chromatography, reversed-phase high-performance liquid chromatography (RP-HPLC), and ion-exchange chromatography.

RP-HPLC is seen as the most powerful method for peptide purification. This technique uses a stationary phase and an aqueous mobile phase containing an organic solvent to rapidly separate 
peptides from a complex mixture [153]. It is also easily scalable, especially since the development of dynamic axial compression (DAC) technology for preparative columns and the availability of excellent and relatively affordable reversed-phase adsorbent materials [154]. Membrane-based separation processes, such as ultrafiltration, are based on the fractionation of peptides according to their molecular weight. Molecular weight cutoff (MWCO) membranes are commonly employed and come in a wide range of sizes (e.g., 10, 5, 3, and $1 \mathrm{kDa}$ MWCO) [104].

Other purification technologies exploit the chemical properties of the targeted peptides. Electromembrane filtration is more selective than membrane filtration because it enables the isolation of bioactive peptides according to both the charge and molecular weight, and it does not require the application of pressure [155]. More recently, affinity chromatography has been demonstrated to be very effective for the purification of bioactive peptides. The principle of this method consists of the formation of specific reversible complexes between the peptides being purified and an immobilized ligand. For example, immobilized copper or nickel on solid supports have been successfully used for the purification of angiotensin I-converting enzyme (ACE) inhibitory peptides [156].

Following the purification steps, peptides can be lyophilized for storage and applications. At the industrial scale of peptide manufacturing for pharmaceutical purposes, commercial-scale tray lyophilizers are used to increase batch volumes and provide better control over the freeze-drying parameters [157]. Despite recent advances in peptide purification, commercial-scale production is still challenged by costly manufacturing processes, which may introduce modifications in the structure of peptides, resulting in alterations or loss of bioactivity [158].

\section{Microalgal Compounds with Antioxidant Properties}

\subsection{Oxidative Stress and the Cell}

Because of increasing concerns over oxidative stress-mediated diseases, many therapeutic approaches and herbal medicines have been developed to identify foods that are rich in natural antioxidants [159]. A wide variety of antioxidant compounds are employed from plants. However, marine resources are gaining more attention since the discovery of new compounds with higher bioactivities than terrestrial plants [23]. In this regard, marine microalgae have been proposed as interesting and important producers of antioxidants $[24,160]$. This is generally attributed to their ability to survive under extremely oxidizing conditions, which increases cellular antioxidant contents or triggers the production of antioxidant secondary metabolites [161].

Under normal physiological conditions, there is a balance (homeostasis) between the prooxidant and antioxidant chemical species; although, an imbalance in favor of prooxidants can lead to oxidative stress [162]. Prooxidants can be classified into oxygen-containing free radicals, generally referred to as reactive oxygen species (ROS), and non-free radical species [163]. The most important ROS species include superoxide $\left(\bullet \mathrm{O}_{2}^{-}\right)$, hydroxyl $(\bullet \mathrm{OH})$, peroxyl $(\mathrm{ROO} \bullet)$, alkoxyl $(\mathrm{RO} \bullet)$, and nitric oxide $\left(\mathrm{NO} \bullet\right.$ ), while the non-free radical species include singlet oxygen $\left({ }^{1} \mathrm{O}_{2}\right)$, hydrogen peroxide $\left(\mathrm{H}_{2} \mathrm{O}_{2}\right)$, and hypochlorous acid (HOCl) [164].

ROS are generated during normal metabolism, i.e., through the respiratory chain in the mitochondria or during cell-mediated immune functions [165]. They can also be introduced by pollution, unhealthy eating habits, smoking, lack of sleep, and irradiation by exposure to ultraviolet (UV) light, X-rays, or gamma rays. If ROS are not effectively neutralized by cellular constituents, they can stimulate free-radical chain reactions that are responsible for cell, tissue, and gene damage [166]. Effects of oxidative stress include lipid membrane peroxidation, mitochondrial swelling and lysis, mutagenic actions, and posttranslational protein modifications $[167,168]$. These sorts of oxidative damage have been found to be linked with several degenerative diseases, e.g., Alzheimer's, Parkinson's, atherosclerosis, rheumatoid arthritis, cancer, as well as accelerated aging [169]. 


\subsection{Carotenoids}

Carotenoids are an integral part of the photosynthetic apparatus that include lipid-soluble carotene and xanthophyll pigments. These compounds harvest light energy, but they also behave as photoprotective agents against free radicals and harsh environmental conditions, e.g., intense solar irradiation and UV $[170,171]$. Carotenoids are naturally produced in a broad assortment of related pigments with varying ratios to harvest the broadest spectrum of light energy. Of note, $\beta$-carotene and astaxanthin represent over $90 \%$ of the total carotenoids in D. salina and H. pluvialis, respectively, when grown at extreme conditions.

The antioxidant activity of carotenoids is attributed to the numerous conjugated double bonds in their structure or the presence of specific groups, such as epoxy, acetyl, allene $(C=C=C)$, or acetylene $(C \equiv C)$ groups $[172,173]$. These chemical groups act by scavenging free radicals and singlet oxygen from reactive species, thus neutralizing them into less harmful molecules [174]. In other cases, the antioxidant activity has been reported to be independent of structure. In such cases, carotenoids can activate the transcription factor, Nrf2 (nuclear factor erythroid-2-related factor 2), which triggers antioxidant gene expression in particular cells and tissues [19].

Of note, the antioxidant activity of microalgal carotenoids was reported to be significantly higher than that of plants or synthetic analogues. The in vitro antioxidant activity of fucoxanthin, a brown xanthophyll found in golden algae, was reported to be $>13$ times higher than $\alpha$-tocopherol, vitamin E [175]. Similarly, astaxanthin, a red keto-carotenoid, was 65 times higher than vitamin $C$ and 100 times more effective than $\alpha$-tocopherol [97].

\subsection{Phenolics}

Phenolic compounds are secondary metabolites commonly found in all terrestrial plants as well as microalgae and cyanobacteria [176]. Phenolics are typically synthesized to protect cells against pathogens and ultraviolet irradiation, and they possess a very wide range of biological activities, including antioxidant properties [22,163,177-180].

It has been demonstrated that the antioxidant activity of phenolic compounds is highly dependent on their chemical structure, characterized by an aromatic ring bearing one or more hydroxyl substituents [181]. The hydroxyl groups contribute to the antioxidant activity through their metal-chelating capability as well as electron/hydrogen donation capacity, generating radical intermediates of greater chemical stability than the initial radicals [182,183]. Moreover, the combined action of hydrophobic benzenoid rings and hydroxyl groups makes phenolics capable of inhibiting different enzymes involved in ROS generation, such as lipoxygenases, cyclooxygenase, and xanthine oxidase $[163,184]$.

The contribution of phenolic compounds from microalgae to antioxidant activity is not very well established, like that of carotenoids. While some of the available research reported a positive correlation between the total antioxidant capacity and the whole phenolic fraction $[22,185,186]$, other examinations presented contradictory results $[182,183,187,188]$. This has been attributed to several factors, such as the quality and the quantity of the phenolic compounds as well as the type of solvent used for the extraction process. Different strains of microalgae were reported to contain between 0.54 and $5.8 \mathrm{mg}_{\text {gallic acid }}{ }^{-1}$ dry weight (DW) when using various polar and non-polar organic solvents $[180,183,186]$. However, under similar experimental conditions, exceptionally higher values of phenolics were reported from Chlorella pyrenoidosa $\left(13.2-25.8 \mathrm{mg} \mathrm{g}^{-1} \mathrm{DW}\right)$ and from Arthrospira platensis (17-43.2 $\mathrm{mg} \mathrm{g}^{-1} \mathrm{DW}$ ) [185]. Higher levels were also detected in extracts from C. vulgaris when pressurized liquid extraction (PLE) was used at elevated temperatures [189].

Generally, the use of polar solvents or a mixture of water and organic solvents allows for better extraction of broad groups of phenolics. While Hajimahmoodi et al. [186] and Machu et al. [185] found that hot water was the best solvent for the extraction of phenolic compounds, Li et al. [183] found that hexane (a very non-polar solvent) had the highest extraction yield of phenolics. However, it is likely that intermediate solvent mixtures would yield many more phenolic compounds. Furthermore, 
little is known about the nature of polyphenolic compounds that are present in microalgae, since only a few articles have assessed the complete profile of phenolic compounds using chromatography methods [185,190,191]. Thus, further identification of phenolic compounds from microalgae is needed to better understand their roles as potential antioxidants.

\subsection{Peptides}

Research in the area of bioactive peptides has increased significantly in the last decade. Natural peptides have reduced side effects when compared to synthetic supplements that may interfere with immune system activity and defense mechanisms, resulting in prooxidant effects [192]. The global interest in bioactive peptides has been accelerated by their wide range of applications as potential treatments for a diverse array of pathological conditions, including hypertension, inflammation, diabetes, and oxidative stress [193-195]. Current sources of bioactive peptides are from plants and animal proteins [196,197], but very rarely microalgae. According to the available literature, only a few genera (e.g., Chlorella, Navicula, Tetraselmis, and Nitzschia) have been investigated and these genera produce numerous bioactive peptides with antioxidant properties [193,198].

The antioxidant properties of bioactive peptides from microalgae have been examined in vitro, but also using cell-based assays. In vitro methods consist of assessing the capacity of bioactive peptides to scavenge reactive oxygen species and free radicals (e.g., 2,2-diphenyl-1-picrylhydrazyl DPPH, hydroxyl, and superoxide anion radicals), to reduce ferric ions or inhibit lipid peroxidation [199]. It should be noted that the measurement of antioxidant activity in vitro has very little similarity to the physiological antioxidant capacity, which has made it challenging to conduct in vivo studies. As a result, it was proposed that the assessment of lipid and protein peroxidation as well as DNA damage are the most appropriate biomarkers to monitor changes in antioxidant activity in vivo [200].

Enzymatic hydrolysis is the most common process for the preparation of antioxidant peptides, which have been tested in the form of crude hydrolysates or purified peptides. It was reported that crude hydrolysates from the chlorophytes, Chlorella pyrenoidosa [201], Chlorella ellipsiodea, and Tetraselmis suecica [202], showed strong antioxidant activity in vitro and on skin fibroblasts. The purified peptides, Val-Glu-Cys-Tyr-Gly-Pro-Asn-Arg-Pro-Glu-Phe and Leu-Asn-Gly-Asp-Val-Trp, from the pepsin hydrolysate of Chlorella vulgaris and Chlorella ellipsiodea, respectively, had strong superoxide and DPPH radical scavenging activities [203,204]. Similarly, two bioactive peptides, Pro-Gly-Trp-Asn-Gln-Trp-Phe-Leu and Val-Glu-Val-Leu-Pro-Pro-Ala-Glu-Leu, isolated from papain hydrolysate of Navicula incerta, demonstrated potent antioxidant properties in HepG2/CYP2E1 cells [205].

The exact mechanisms of the antioxidant action of protein hydrolysates have not yet been clearly elucidated. However, it was recognized that the antioxidant activity of peptides was positively influenced by various characteristics of their chemical structure, namely small molecular weight, the composition and sequence of amino acids, the degree of hydrophobicity, the presence of an indole/imidazole/pyrrolidine ring, along with the steric structure at the C- and N-terminal region [206-208]. The use of quantitative structure-activity relationship (QSAR) modeling of antioxidative peptides for scavenging radicals has provided additional evidence on the importance of the C-terminal region over the N-terminal for antioxidant potency [209].

\section{Microalgal Compounds with Antihypertensive Properties}

\subsection{Hypertension and Heart Health}

Hypertension is a major health concern worldwide. It is recognized to be the main cause of death and a leading risk factor of several chronic ailments, including cardiovascular disease, stroke, renal disease, and diabetes [210]. The regulation of blood pressure in the body involves a multitude of complex systems that are governed by ACE in the renin-angiotensin-aldosterone system. ACE catalyzes the conversion of inactive Angiotensin-I (Ag I) to Angiotensin-II (Ag II), a potent vasoconstrictor 
peptide that binds directly to Angiotensin II Type 1 Receptor in the vascular smooth muscle cells to induce a potent hypertensive effect [211]. Furthermore, Ag II stimulates the secretion of aldosterone in the adrenal cortex, which promotes sodium and thus, water reabsorption in the distal tubules [212]. As a result, the volume of fluid in the body increases, implying an increase in blood pressure. On the other hand, Ag II stimulates the production of the superoxide anion and hydrogen peroxide in the polymorphonuclear leucocytes, which elicits an endothelium-dependent vasocontraction effect through the inactivation of endothelium-derived relaxing factor and prostacyclin [213]. Besides the activation of Ag II, ACE plays a concomitant role in the regulation of hypertension via the inactivation of an endothelium-dependent vasodilatory peptide, bradykinin [214].

The need to regulate hypertension has led to the development of ACE inhibitors. To date, different classes of synthetic ACE inhibitors are available on the market, such as captopril, lisinopril, and enalapril. This class of drugs has demonstrated clinical efficacy in terms of treating hypertension and reducing mortality $[215,216]$. Although, treatments with ACE inhibitors have also been associated with unpleasant or intolerable side effects, including hypotension, angioedema, coughing, dizziness, headaches, nausea, and renal damage [217]. Synthetic antihypertensive drugs also represent a major burden on global healthcare costs. Thus, there is great interest in the use of antihypertensive compounds from natural resources.

\subsection{Peptides}

Food-derived bioactive peptides have demonstrated their antihypertensive properties through the inhibition of enzymes involved in the regulation of mammalian blood pressure, e.g., ACE and renin $[217,218]$. In addition, certain peptides have demonstrated the ability to enhance the endothelial nitric oxide synthase pathway, leading to an increase in nitric oxide levels within the vascular walls, thus promoting vasodilation [219]. Other peptides were reported to block the interactions between $\mathrm{Ag}$ II, a vasoconstrictor, and angiotensin receptors, which contributes to reducing blood pressure [220]. However, ACE-inhibitory activity is the most-studied metabolic pathway for the development of antihypertensive peptides.

Various sources of plant and animal proteins, mainly from dairy products and fish, have been used to produce ACE-inhibitory peptides (for a review, see Monroe and Fitzgerald [221]), but the use of microalgal proteins has been very limited. Thus far, Chlorella vulgaris, C. ellipsiodea, Arthrospira platensis, and Nannochloropsis oculata have been used to produce ACE-inhibitory peptides [193]. Their effectiveness in lowering blood pressure has been reported extensively using both in vitro and animal studies. A purified peptide isolated from the pepsin hydrolysate of algae protein waste from Chlorella vulgaris, with the amino acid sequence Val-Glu-Cys-Tyr-Gly-Pro-Asn-Arg-Pro-Gln-Phe, was found to possess ACE-inhibitory activity with an $\mathrm{IC}_{50}=29.6 \mu \mathrm{M}$ [222]. Two purified peptides, Gly-Met-Asn-Asn-Leu-Thr-Pro and Leu-Glu-Gln, from the cultured marine microalga, Nannochloropsis oculata, showed ACE inhibitory activity with $\mathrm{IC}_{50}$ values of $123 \mu \mathrm{M}$ and $173 \mu \mathrm{M}$, respectively [119]. Similarly, a potent ACE inhibitory peptide from the marine Chlorella ellipsoidea composed of only four amino acids, Val-Glu-Gly-Tyr, was reported to have ACE inhibitory activity $\left(\mathrm{IC}_{50}\right.$ value $\left.=128.4 \mu \mathrm{M}\right)$ as well as an antihypertensive effect in spontaneously hypertensive rats (SHR) when administrated orally [223].

The intensity of the antihypertensive effect is strongly influenced by the structure and composition of the bioactive peptides [224]. Results of analytical and chemometric experiments showed that ACE-inhibitory peptides preferred to bind to C-terminal or N-terminal catalytic sites of ACE [225]. Moreover, it was suggested that substrates containing amino acids with cyclic or aromatic rings (e.g., Pro, Phe, Tyr, Trp) at their C-terminus and hydrophobic amino acids, especially those with aliphatic chains (e.g., Gly, Ile, Leu, Val), at their N-terminus were thought to enhance ACE-inhibition [226,227]. Despite evidence citing the importance of the $\mathrm{C}$-terminal domain in the role of blood pressure regulation, the N-terminal domain was deemed the most important for ACE inhibition; the benefits consisted mainly of higher blockage of Angiotensin II production and better prevention of organ damage [228]. 


\section{Microalgal Compounds with Anti-Inflammatory Properties}

\subsection{Inflammation in the Body}

Inflammation is a natural defense mechanism against pathogens. Although, chronic episodes of inflammation may cause renal, neurodegenerative, and cardiovascular diseases, and it is a leading cause of cancer, diabetes, and obesity [229]. There is increasing evidence that oxidative stress is the common factor underlying several inflammatory pathways, e.g., an increase in reactive oxygen species (ROS) has been suggested to be directly involved in Alzheimer's disease. This is supported by the overproduction of ROS in early-stage patients that results in cleaving and misfolding of the amyloid precursor protein to amyloid beta-peptide $(A \beta)$, which induces mitochondrial dysfunction and facilitates the formation of amyloid plaques [230]. The disease pathology upregulates pro-inflammatory cytokines and free radical generation, which subsequently stimulates the production of $A \beta$ peptide and other inflammatory pathways [231]. Additionally, ROS generated in brain tissues can modulate synaptic and non-synaptic communication between neurons that may result in neuroinflammation and cellular death, and subsequently in neurodegeneration and memory loss [232].

Results from epidemiological and experimental studies strongly suggest that the use of medicinal plants or dietary supplements with bioactive plant-based extracts can have anti-inflammatory effects [233]. Contradictory results have been also reported [234]. Similarly, natural products from microalgae have been investigated for their anti-inflammatory properties. The most studied compounds are carotenoids, PUFAs, and modified carbohydrates [229,235]. However, there are still many other microalgal metabolites that are also reported to suppress chronic inflammation and alleviate disease-associated symptoms, including phycobiliproteins, phenolic compounds, and various terpenoids $[229,236]$.

Algal extracts have exhibited anti-inflammatory activities, notably through the inhibited production of pro-inflammatory cytokines and eicosanoids and the reduced expression of pro-inflammatory genes [237]. The mechanisms of action from these algal metabolites are very diverse and include the modulation of enzyme activities (e.g., phospholipase A2, cyclooxygenase-2 (COX2), nitric oxide synthase (NOS)), regulation of cellular activities, and the interference of two major signaling pathways [238]. These include the nuclear factor $\kappa B(\mathrm{NF}-\kappa \mathrm{B})$ and the mitogen-activated protein kinase pathways, which play a key role in the production of various proinflammatory mediators. Algal compounds in extracts may also have anti-inflammatory properties combined with their antioxidant properties [239].

\subsection{Omega Fatty Acids}

Long-chain PUFAs, including EPA and DHA, are reported to have a therapeutic role in a variety of inflammatory pathologies, such as Alzheimer's disease, arthritis, and lupus [240]. A growing number of studies in animal and in vitro trials support the anti-inflammatory properties of microalgal oils. Nauroth et al. [86] reported that the use of docosapentaenoic acid (DPA), another omega-3 PUFA, from Schizochytrium sp. inhibited the lipopolysaccharide (LPS)-stimulated secretion of interleukin (IL)-1 beta and tumor necrosis factor-alpha (TNF- $\alpha$ ) in human peripheral blood mononuclear cells. The authors also found that rats fed an algal oil containing DPA ( $16 \%$ of the total fatty acids) and DHA ( $40 \%$ of the total fatty acids) significantly reduced inflammation in paw edema model rats in comparison to the control [86]. Banskota et al. [241,242] also reported anti-inflammatory effects in RAW 264.7 macrophage cells from lipid extracts containing monogalactosyldiacylglycerols from Tetraselmis chuii, Chlorella sorokiniana, and Chondrus crispus. Furthermore, the use of microalgal oils in the diet, especially those that are rich in omega- 3 fatty acids, has been demonstrated to induce chemopreventative effects on azoxymethane-induced colonic aberrant crypt foci functions [243].

Of note, macroalgal lipids have also been explored for their effects, and Khan et al. [244] reported the anti-inflammatory properties of omega-3 fatty acids from the edible brown seaweed, Undaria pinnatifid; stearidonic acid (SDA) was active against phorbol myristate acetate-induced ear inflammation 
while EPA was active against edema, erythema, and blood flow in mice. Vo et al. [245] demonstrated that PUFAs from the brown seaweed, Ishige okamurae, were involved in alleviating inflammation due to an allergic response by reducing histamine release and modulating inflammatory cytokine production in human basophilic KU812F cells. Thus, it is suggested that lipid extracts rich in PUFAs (from microor macro-algae) could be beneficial as functional food ingredients to control inflammation.

\subsection{Carotenoids}

Carotenoids are well known for their anti-inflammatory properties. While they are structurally related, they can have diverse mechanisms of action. In particular, astaxanthin has received considerable attention due to its anti-inflammatory properties. Results from in vitro and in vivo studies showed that astaxanthin produced by the microalga, Haematococcus pluvialis, possessed inhibitory effects on LPS-induced inflammation [246]. In fact, the anti-inflammatory effects of astaxanthin (dosage of $100 \mathrm{mg} / \mathrm{kg}$ ) were more pronounced than that of a common anti-inflammatory drug, prednisolone (dosage at $10 \mathrm{mg} / \mathrm{kg}$ ) [246].

The inhibitory activities of xanthophyll carotenoids have been demonstrated for inducible NOS or COX-2 enzymes in cell lines (e.g., BV2 microglial cells and RAW 264.7 macrophage cells) that were stimulated by LPS $[247,248]$. Astaxanthin has been reported to inhibit the production of nitrous oxide (NO), prostaglandin E2 (PGL2), and to lower the levels of proinflammatory cytokines, TNF- $\alpha$, IL-1 $\beta$, and IL-6 $[247,249]$. In addition, treatment with astaxanthin at $5 \mathrm{mM}$ was found to improve the phagocytic and microbicide function, and to reduce the oxidative damage to lipids and proteins in human neutrophils [250]. Furthermore, cells pre-incubated with astaxanthin restored expression levels of SHP-1, a small heterodimer protein tyrosine phosphatase, and reduced the expression of NF-kB [249].

Results gathered from animal studies were in accordance with those of in vitro trials. Bennedsen et al. [251] reported that astaxanthin from H. pluvialis at $200 \mathrm{mg} / \mathrm{kg}$ reduced the levels of gastric inflammation in Helicobacter pylori-infected mice following a treatment period of 10 days. The decrease in inflammation and the reduction of mucosa-related bacterial loads in the stomachs of infected mice were attributed to the action of astaxanthin to block the release of interferons, which boosts IL-4 release in splenocytes. A clinical study was also conducted on healthy young women, where it was demonstrated that the ingestion of $2 \mathrm{mg}$ of astaxanthin daily for 8 weeks lowered the C-reactive protein in blood levels [252]. In the same study, astaxanthin was also found to reduce ROS production through downregulation of NF- $\mathrm{KB}$ and AP-1 transcription factors, as well as reducing the production of inflammatory cytokines [252].

\subsection{Polysaccharides}

Algae synthesize many structurally-diverse carbohydrates with different types of glycosidic bonds. They can be classified as homo- and hetero-polysaccharides, sulfated polysaccharides (SPS), glyco-proteins/peptides, and pectins [253]. However, the relationship between the structures of polysaccharides and their biological functions are not well characterized because of the diversity and complexity of these polymers, namely the absence of monomeric and structural information [254].

Sulfated polysaccharides (SPS) from micro- and macro-algae are the most studied bioactive group of carbohydrates with anti-inflammatory activity [255]. These compounds can vary widely in their composition, i.e., types of monosaccharides, and their degree of sulfation. Several microalgal genera have been explored for their anti-inflammatory properties, including Porphyridium (Rhodophyta), Phaeodactylum (Heterokonts), and Chlorella (Chlorophyta). Guzman et al. [108] reported that crude polysaccharide extracts from Chlorella stigmatophora and Phaeodactylum tricornutum demonstrated an anti-inflammatory response in a paw edema test. Of note, SPS from P. tricornutum showed a direct stimulatory effect on the immune cells as shown with in vitro and in vivo assays. Similarly, Matsui et al. [256] found that SPS from Porphyridium inhibited the migration of leukocytes to the sites of inflammation in vitro, and inhibited the development of erythema in vivo. 
Besides microalgae, extensive research exists on the bioactive carbohydrates from seaweeds. Albuquerque et al. [257] showed that heterofucan (sulfated L-fucose) from the brown algae, Dictyota menstrualis, decreased inflammation by binding to the cell surface of polymorphonuclear cells, which completely inhibits the migration of the leukocytes into the peritoneal cavity of injured tissue in mice without the production of pro-inflammatory cytokines. In another study, Kang et al. [258], found that fucoidan (sulfated alpha-L-glucan) from Ecklonia cava possessed inhibitory effects on the inducible NOS and COX-2 enzymes, which limited the production of NO and PGL2 in RAW 264.7 macrophage cells. Furthermore, Li et al. [259] reported that a fucoidan from Lamanaria japonica reduced inflammation of damaged myocardium cells in rats by inactivating the secretion of the cytokines, HMGB1 and NF- $\mathrm{KB}$, two immunoproteins that are secreted during inflammatory responses and necrosis.

\section{Future Prospects}

Within the context of global population growth and the availability of terrestrial food products, microalgae may present reliable and sustainable substitutes to commonly used commodities from animal or plant origins. However, to date, only a limited number of strains, mainly the cyanobacterium, Arthrospira, and some green microalgae (e.g., Chlorella, Dunaliella, and Haematococcus), have been utilized for the commercial production of a rather limited number of products. The shift from a niche market to the widespread use of algal products as food commodities will require extensive research and development. This would include the screening of new species or the improvement of existing strains by genetic engineering and modifications towards the development of microalgae with enhanced production of targeted metabolites. In the end, it is essential that microalgal cultivation and processing can be performed economically to ensure low-cost production that can compete with synthetic or biological production from other organisms.

There has been a growing demand for functional foods and nutraceuticals with targeted health benefits. In this context, the use of protein hydrolysates and bioactive peptides has gained interest for the prevention of illness and the improvement of symptoms from several diseases. Available studies on peptides of microalgal origin, although not very abundant, have provided evidence of promising in vitro biological properties. However, more in vivo and clinical trials are needed to determine the bioavailability of peptides after oral administration, especially since loss of bioactivity may occur due to hydrolysis and/or absorption of peptides in the gastrointestinal tract. In order to maintain the bioactivity of peptides, several strategies are being used, such as microencapsulation, nanoencapsulation, or chemical modification. A better understanding of the structure-activity relationship using bioinformatics should enable the development of peptides with an enhanced bioactivity and help to predict non-desirable effects, such as hemolysis.

\section{Conclusions}

Whole microalgal biomass and extracted high-value co-products are currently used in nutraceuticals and as ingredients in functional foods. It is widely recognized that compounds from microalgal extracts have greater biological and economical value than dried biomass. Additionally, purified compounds are preferable given that there are many undefined biochemicals, potential toxins, and heavy metals in whole microalgal biomass that could be unsafe for consumption and cause serious health conditions. Moreover, literature is needed to inform consumers about the content and acceptability of microalgal products.

The supply of high-value algal products is challenged by the overall costs of production, including cultivation systems and maintenance, limited culture productivity, and the biorefining processes. While open ponds are the most economical choice for large-scale cultivation, they are more prone to contamination, thus closed PBRs are preferred if the selected strains synthesize valuable products that can justify the cost of the system. Harvesting and refining the biomass can also be very expensive, and the costs are largely dependent on the selected processes. Traditional methods for the extraction of high-value metabolites often rely on the use of organic solvents, and residual solvents in the products 
can compromise health. Thus, greener technologies, like supercritical fluid extraction and enzymatic hydrolysis, are presented as emerging techniques for the isolation of high-value algal products.

Despite the challenges of large-scale cultivation, there is a clear demand for microalgal ingredients in foods, supplements, and potential pharmaceuticals. However, much more research is needed in this field to characterize the biochemical content of candidate microalgae to fully understand their benefits and possible concerns. Research on microalgal protein hydrolysates and purified peptides have demonstrated potential as antioxidants and antihypertensive compounds. Furthermore, given that only a few production strains of microalgae have been investigated (out of more than hundreds of thousands of predicted strains), there are immense opportunities for the discovery of novel bioactive metabolites, including the identification of compounds with potential antimicrobial, antifungal, antitumorigenic, and related activities.

Funding: This research received no external funding.

Acknowledgments: The authors are grateful to the Universiti of Putra Malaysia for their financial support.

Conflicts of Interest: The authors declare no conflict of interest.

\section{References}

1. McFadden, G.I. Primary and secondary endosymbiosis and the origin of plastids. J. Phycol. 2001, 37, 951-959. [CrossRef]

2. Leliaert, F.; Smith, D.R.; Moreau, H.; Herron, M.D.; Verbruggen, H.; Delwiche, C.F.; De Clerck, O. Phylogeny and molecular evolution of the green algae. Crit. Rev. Plant Sci. 2012, 31, 1-46. [CrossRef]

3. Hou, Y.; Lin, S. Distinct gene number-genome size relationships for eukaryotes and non-eukaryotes: Gene content estimation for dinoflagellate genomes. PLoS ONE 2009, 4, e6978. [CrossRef]

4. Adl, S.M.; Simpson, A.G.; Lane, C.E.; Lukeš, J.; Bass, D.; Bowser, S.S.; Brown, M.W.; Burki, F.; Dunthorn, M.; Hampl, V.; et al. The revised classification of eukaryotes. J. Eukaryot. Microbiol. 2012, 59, 429-514. [CrossRef]

5. Wright, S.W.; Jeffrey, S.W. Pigment markers for phytoplankton production. In Marine Organic Matter: Biomarkers, Isotopes and DNA; Springer: Berlin, Germany, 2006; pp. 71-104.

6. Botana, L.M.; Alfonso, A. Phycotoxins: Chemistry and Biochemistry; John Wiley \& Sons: Hoboken, NJ, USA, 2015.

7. Manning, S.R.; Nobles, D.R. Impact of Global Warming on Water Toxicity: Cyanotoxins. Curr. Opin. Food Sci. 2017, 18, 14-20. [CrossRef]

8. Demirbas, A.; Demirbas, M.F. Importance of algae oil as a source of biodiesel. Energy Conv. Manag. 2011, 52, 163-170. [CrossRef]

9. Craggs, R.J.; Adey, W.H.; Jenson, K.R.; St John, M.S.; Green, F.B.; Oswald, W.J. Phosphorus removal from wastewater using an algal turf scrubber. Water Sci. Technol. 1996, 33, 191-198. [CrossRef]

10. Enzing, C.; Ploeg, M.; Barbosa, M.; Sijtsma, L. Microalgae-based products for the food and feed sector: An outlook for Europe. JRC Sci. Policy Rep. 2014, 19-37. [CrossRef]

11. Leu, S.; Boussiba, S. Advances in the Production of High-Value Products by Microalgae. Ind. Biotechnol. 2014, 10, 169-183. [CrossRef]

12. Spolaore, P.; Joannis-Cassan, C.; Duran, E.; Isambert, A. Commercial applications of microalgae. J. Biosci. Bioeng. 2006, 101, 87-96. [CrossRef]

13. Richardson, J.W.; Johnson, M.D.; Zhang, X.; Zemke, P.; Chen, W.; Hub, Q. A financial assessment of two alternative cultivation systems and their contributions to algae biofuel economic viability. Algal Res. 2014, 4, 96-104. [CrossRef]

14. Borowitzka, M.A. High-value products from microalgae-Their development and commercialisation. J. Appl. Phycol. 2013, 25, 743-756. [CrossRef]

15. Marketsand Markets. Carotenoids Market by Type (Astaxanthin, Beta-Carotene, Canthaxanthin, Lutein, Lycopene, \& Zeaxanthin), Source (Synthetic and Natural), Application (Supplements, Food, Feed, and Cosmetics), by Region-Global Trends and Forecasts to 2021. Available online: http://www. marketsandmarkets.com/Market-Reports/carotenoid-market-158421566.html (accessed on 12 October 2017). 
16. Hu, G.P.; Yuan, J.; Sun, L.; She, Z.G.; Wu, J.H.; Lan, X.J.; Zhu, X.; Lin, Y.C.; Chen, S.P. Statistical research on marine natural products based on data obtained between 1985 and 2008. Mar. Drugs 2011, 9, 514-525. [CrossRef]

17. de Jesus Raposo, M.F.; de Morais, R.M.S.C.; de Morais, A.M.M.B. Bioactivity and applications of sulphated polysaccharides from marine microalgae. Mar. Drugs 2013, 11, 233-252. [CrossRef]

18. Pouvreau, J.B.; Morançais, M.; Taran, F.; Rosa, P.; Dufossé, L.; Guérard, F.; Pin, S.; Fleurence, J.; Pondaven, P. Antioxidant and free radical scavenging properties of marennine, a blue-green polyphenolic pigment from the diatom Haslea ostrearia (Gaillon/Bory) Simonsen responsible for the natural greening of cultured oysters. J. Agric. Food Chem. 2008, 56, 6278-6286. [CrossRef] [PubMed]

19. Gammone, M.A.; Riccioni, G.; D'Orazio, N. Marine carotenoids against oxidative stress: Effects on human health. Mar. Drugs 2015, 13, 6226-6246. [CrossRef] [PubMed]

20. Peng, J.; Yuan, J.P.; Wu, C.F.; Wang, J.H. Fucoxanthin, a marine carotenoid present in brown seaweeds and diatoms: Metabolism and bioactivities relevant to human health. Mar. Drugs 2011, 9, 1806-1828. [CrossRef] [PubMed]

21. Haimeur, A.; Ulmann, L.; Mimouni, V.; Guéno, F.; Pineau-Vincent, F.; Meskini, N. Tremblin, G. The role of Odontella aurita, a marine diatom rich in EPA, as a dietary supplement in dyslipidemia, platelet function and oxidative stress in high-fat fed rats. Lipids Health Dis. 2012, 11, 147. [CrossRef]

22. Goiris, K.; Muylaert, K.; Fraeye, I.; Foubert, I.; De Brabanter, J.; De Cooman, L. Antioxidant potential of microalgae in relation to their phenolic and carotenoid content. J. Appl. Phycol 2012, 24, 1477-1486. [CrossRef]

23. Lauritano, C.; Andersen, J.H.; Hansen, E.; Albrigtsen, M.; Escalera, L.; Esposito, F.; Helland, K.; Hanssen, K.Ø.; Romano, G.; Ianora, A. Bioactivity screening of microalgae for antioxidant, anti-Inflammatory, anticancer, anti-Diabetes, and antibacterial activities. Front. Mar. Sci. 2016, 3, 68. [CrossRef]

24. Xia, S.; Gao, B.; Li, A.; Xiong, J.; Ao, Z.; Zhang, C. Preliminary characterization, antioxidant properties and production of chrysolaminarin from marine diatom Odontella aurita. Mar. Drugs 2014, 12, 4883-4897. [CrossRef]

25. Lee, J.B.; Hayashi, K.; Hirata, M.; Kuroda, E.; Suzuki, E.; Kubo, Y.; Hayashi, T. Antiviral sulfated polysaccharide from Navicula directa, a diatom collected from deep-sea water in Toyama Bay. Biol. Pharm. Bull. 2006, 29, 2135-2139. [CrossRef]

26. Beetul, K.; Gopeechund, A.; Kaullysing, D.; Mattan-Moorgawa, S.; Puchooa, D.; Bhagooli, R. Challenges and Opportunities in the Present Era of Marine Algal Applications. In Algae-Organisms for Imminent Biotechnology; Thajuddin, N., Dhanasekaran, D., Eds.; IntechOpen: London, UK, 2016; pp. 237-276.

27. Hur, S.B.; Bae, J.H.; Youn, J.Y.; Jo, M.J. KMMCC-Korea Marine Microalgae Culture Center: List of strains. Algae 2015, 30, S1. [CrossRef]

28. d'Avout d'Auerstaedt, R.; Passion Spiruline Ltd. Antenna Technologies France. Unpublished. Private Communication, 2014.

29. Pulz, O.; Broneske, J.; Waldeck, P. IGV GmbH experience report, industrial production of microalgae under controlled conditions: Innovative prospects. In Handbook of Microalgal Culture: Applied Phycology and Biotechnology; Richmond, A., Hu, Q., Eds.; John Wiley \& Sons: Oxford, UK, 2013; pp. 445-460.

30. Abu Zaid, A.A.; Hammad, D.M.; Sharaf, E.M. Antioxidant and anticancer activity of Spirulina platensis water extracts. Int. J. Pharmacol. 2015, 11, 846-851. [CrossRef]

31. Tang, G.; Suter, P.M. Vitamin A, nutrition, and health values of algae: Spirulina, Chlorella, and Dunaliella. J. Pharm. Nutr. Sci. 2011, 1, 111-118. [CrossRef]

32. Hernández-Corona, A.; Nieves, I.; Meckes, M.; Chamorro, G.; Barron, B.L. Antiviral activity of Spirulina maxima against herpes simplex virus type 2 . Antivir. Res. 2002, 56, 279-285. [CrossRef]

33. Liu, J.; Hu, Q. Chlorella: Industrial production of cell mass and chemicals. In Handbook of Microalgal Culture: Applied Phycology and Biotechnology; Richmond, A., Hu, Q., Eds.; Wiley: Oxford, UK, 2013; pp. 327-338.

34. Reyna-Martinez, R.; Gomez-Flores, R.; López-Chuken, U.; Quintanilla-Licea, R.; Caballero-Hernandez, D.; Rodríguez-Padilla, C.; Beltrán-Rocha, J.C.; Tamez-Guerra, P. Antitumor activity of Chlorella sorokiniana and Scenedesmus sp. microalgae native of Nuevo León State, México. Peer] 2018, 6, e4358. [CrossRef]

35. Ryu, N.H.; Lim, Y.; Park, J.E.; Kim, J.; Kim, J.Y.; Kwon, S.W.; Kwon, O. Impact of daily Chlorella consumption on serum lipid and carotenoid profiles in mildly hypercholesterolemic adults: A double-blinded, randomized, placebo-controlled study. Nutr. J. 2014, 13, 57. [CrossRef] 
36. Medina-Jaritz, N.B.; Carmona-Ugalde, L.F.; Lopez-Cedillo, J.C.; Ruiloba-De Leon, F.S.L. Antibacterial activity of methanolic extracts from Dunaliella salina and Chlorella vulgaris. FASEB J. 2013, 27, 1167-5.

37. Tiberg, E.; Dreborg, S.; Björkstén, B. Allergy to green algae (Chlorella) among children. J. Allergy Clin. Immunol. 1995, 96, 257-259. [CrossRef]

38. Yim, H.E.; Yoo, K.H.; Seo, W.H.; Won, N.H.; Hong, Y.S.; Lee, J.W. Acute tubulointerstitial nephritis following ingestion of Chlorella tablets. Pediat. Nephrol. 2007, 22, 887-888. [CrossRef]

39. Griffith, H.W. Vitamins, Herbs, Minerals \& Supplements: The Complete Guide; Fisher Books: Tucson, AZ, USA, 1998.

40. Dagnelie, P.C.; van Staveren, W.A.; van den Berg, H. Vitamin B-12 from algae appears not to be bioavailable. Am. J. Clin. Nutr. 1991, 53, 695-697. [CrossRef]

41. Gilroy, D.J.; Kauffman, K.W.; Hall, R.A.; Huang, X.; Chu, F.S. Assessing potential health risks from microcystin toxins in blue-green algae dietary supplements. Environ. Health Perspect. 2000, 108, 435-439. [CrossRef]

42. Weiß, A. Food Supplements from Blue-Green Algae do More Harm than Good. BioLAGO 2013. Healthcare Industry BW, 2013. Available online: https://www.gesundheitsindustrie-bw.de/en/article/news/foodsupplements-from-blue-green-algae-do-more-harm-than-good/ (accessed on 14 April 2018).

43. Carvalho, A.P.; Malcata, F.X. Effect of culture media on production of polyunsaturated fatty acids by Pavlova lutheri. Cryptogamie Algol. 2000, 21, 59-71. [CrossRef]

44. Brown, M.R.; Dunstan, G.A.; Jeffrey, S.W.; Volkman, J.K.; Barrett, S.M.; LeRoi, J.M. The influence of irradiance on the biochemical composition of the Prymnesiophyte Isochrysis sp. (clone T-ISO). J. Phycol. 1993, 29, 601-612. [CrossRef]

45. Brown, M.R. The amino-acid and sugar composition of 16 species of microalgae used in mariculture. J. Exp. Mar. Biol. Ecol. 1991, 145, 79-99. [CrossRef]

46. Tibbetts, S.M.; Milley, J.E.; Lall, S.P. Chemical composition and nutritional properties of freshwater and marine microalgal biomass cultured in photobioreactors. J. Appl. Phycol. 2015, 27, 1109-1119. [CrossRef]

47. Becker, E.W. Micro-algae as a source of protein. Biotechnol. Adv. 2007, 25, 207-210. [CrossRef]

48. Barbarino, E.; Lourenço, S.O. An evaluation of methods for extraction and quantification of protein from marine macro-and microalgae. J. Appl. Phycol. 2005, 17, 447-460. [CrossRef]

49. Slocombe, S.P.; Ross, M.; Thomas, N.; McNeill, S.; Stanley, M.S. A rapid and general method for measurement of protein in micro-algal biomass. Bioresource Technol. 2013, 129, 51-57. [CrossRef]

50. Kent, M.; Welladsen, H.M.; Mangott, A.; Li, Y. Nutritional evaluation of Australian microalgae as potential human health supplements. PLoS ONE 2015, 10, e0118985. [CrossRef]

51. González López, C.V.; García, M.D.C.C.; Fernández, F.G.A.; Bustos, C.S.; Chisti, Y.; Sevilla, J.M.F. Protein measurements of microalgal and cyanobacterial biomass. Bioresource Technol. 2010, 101,7587-7591. [CrossRef]

52. Velasco, L.A.; Carrera, S.; Barros, J. Isolation, culture and evaluation of Chaetoceros muelleri from the Caribbean as food for the native scallops, Argopecten nucleus and Nodipecten nodosus. Lat. Am. J. Aquat. Res. 2016, $44,557-568$.

53. Schwenzfeier, A.; Wierenga, P.A.; Gruppen, H. Isolation and characterization of soluble protein from the green microalgae Tetraselmis sp. Bioresource Technol. 2011, 102, 9121-9127. [CrossRef]

54. Ricketts, T.R. On the chemical composition of some unicellular algae. Phytochemistry 1966, 5, 67. [CrossRef]

55. da Silva Gorgônio, C.M.; Aranda, D.A.G.; Couri, S. Morphological and chemical aspects of Chlorella pyrenoidosa, Dunaliella tertiolecta, Isochrysis galbana and Tetraselmis gracilis microalgae. Nat. Sci. 2013, 5, 783.

56. Chisti, Y. Biodiesel from microalgae. Biotechnol. Adv. 2007, 25, 294-306. [CrossRef]

57. Williams, P.J.L.B.; Laurens, L.M. Microalgae as biodiesel \& biomass feedstocks: Review \& analysis of the biochemistry, energetics \& economics. Energy Environ. Sci. 2010, 3, 554-590.

58. Batista, A.P.; Gouveia, L.; Bandarra, N.M.; Franco, J.M.; Raymundo, A. Comparison of microalgal biomass profiles as novel functional ingredient for food products. Algal Res. 2013, 2, 164-173. [CrossRef]

59. Graziani, G.; Schiavo, S.; Nicolai, M.A.; Buono, S.; Fogliano, V.; Pinto, G.; Pollio, A. Microalgae as human food: Chemical and nutritional characteristics of the thermo-acidophilic microalga Galdieria sulphuraria. Food Func. 2013, 4, 144-152. [CrossRef]

60. Milovanovic, I.; Misan, A.; Saric, B.; Kos, J.; Mandic, A.; Simeunovic, J.; Kovac, D. Evaluation of protein and lipid content and determination of fatty acid profile in selected species of cyanobacteria. In Proceedings of the 6th Central European Congress on Food, CEFood2012, Novi Sad, Serbia, 23-26 May 2012. 
61. Plaza, M.; Herrero, M.; Cifuentes, A.; Ibanez, E. Innovative natural functional ingredients from microalgae. J. Agric. Food Chem. 2009, 57, 7159-7170. [CrossRef]

62. Doucha, J.; Lívanský, K. Influence of processing parameters on disintegration of Chlorella cells in various types of homogenizers. Appl. Microbiol. Biotechnol. 2008, 81, 431. [CrossRef]

63. Arad, S.M.; Levy-Ontman, O. Red microalgal cell-wall polysaccharides: Biotechnological aspects. Curr. Opin. Biotechnol. 2010, 21, 358-364. [CrossRef]

64. Nakamura, Y.; Takahashi, J.I.; Sakurai, A.; Inaba, Y.; Suzuki, E.; Nihei, S.; Fujiwara, S.; Tsuzuki, M.; Miyashita, H.; Ikemoto, H.; et al. Some cyanobacteria synthesize semi-amylopectin type $\alpha$-polyglucans instead of glycogen. Plant Cell Physiol. 2005, 46, 539-545. [CrossRef]

65. Busi, M.V.; Barchiesi, J.; Martín, M.; Gomez-Casati, D.F. Starch metabolism in green algae. Starch-Stärke 2014, 66, 28-40. [CrossRef]

66. McCracken, D.A.; Cain, J.R. Amylose in floridean starch. New Phytol. 1981, 88, 67-71. [CrossRef]

67. Gügi, B.; Le Costaouec, T.; Burel, C.; Lerouge, P.; Helbert, W.; Bardor, M. Diatom-specific oligosaccharide and polysaccharide structures help to unravel biosynthetic capabilities in diatoms. Mar. Drugs 2015, 13, 5993-6018. [CrossRef]

68. Dismukes, G.C.; Carrieri, D.; Bennette, N.; Ananyev, G.M.; Posewitz, M.C. Aquatic phototrophs: Efficient alternatives to land-based crops for biofuels. Curr. Opin Biotechnol. 2008, 19, 235-240. [CrossRef]

69. Myklestad, S. Production of carbohydrates by marine planktonic diatoms. I. Comparison of nine different species in culture. J. Exp. Mar. Biol. Ecol. 1974, 15, 261-274. [CrossRef]

70. Qu, L.; Ren, L.J.; Huang, H. Scale-up of docosahexaenoic acid production in fed-batch fermentation by Schizochytrium sp. based on volumetric oxygen-transfer coefficient. Biochem. Eng. J. 2013, 77, 82-87. [CrossRef]

71. Rodolfi, L.; Chini Zittelli, G.; Bassi, N.; Padovani, G.; Biondi, N.; Bonini, G.; Tredici, M.R. Microalgae for oil: Strain selection, induction of lipid synthesis and outdoor mass cultivation in a low-cost photobioreactor. Biotechnol. Bioeng. 2009, 102, 100-112. [CrossRef]

72. Dunstan, G.A.; Volkman, J.K.; Barrett, S.M.; Garland, C.D. Changes in the lipid composition and maximisation of the polyunsaturated fatty acid content of three microalgae grown in mass culture. J. Appl. Phycol. 1993, 5, 71-83. [CrossRef]

73. Guschina, I.A.; Harwood, J.L. Lipids and lipid metabolism in eukaryotic algae. Prog. Lipid Res. 2006, 45, 160-186. [CrossRef]

74. Richmond, A. Biological principles of mass cultivation. In Handbook of Microalgal Culture: Biotechnology and Applied Phycology; Blackwell Publishing Ltd.: Oxford, UK, 2004; pp. 83-90.

75. Muller-Feuga, A.; Moal, J.; Kaas, R. The microalgae of aquaculture. In Live feeds in Marine Aquaculture; Støttrup, J.G., McEvoy, L.A., Eds.; Blackwell Science: Oxford, UK, 2003; pp. 206-252.

76. Michalak, I.; Chojnacka, K.; Saeid, A. Plant Growth Biostimulants, Dietary Feed Supplements and Cosmetics Formulated with Supercritical $\mathrm{CO}_{2}$ Algal Extracts. Molecules 2017, 22, 66. [CrossRef]

77. Panis, G.; Carreon, J.R. Commercial astaxanthin production derived by green alga Haematococcus pluvialis: A microalgae process model and a techno-economic assessment all through production line. Algal Res. 2016, 18, 175-190. [CrossRef]

78. Oilgae. Chlorella from Algae and Its Uses. Available online: http://www.oilgae.com/non_fuel_products/ chlorella.html (accessed on 27 January 2018).

79. Oilgae. Comprehensive Report on Attractive Algae Product Opportunities. Available online: https: //secure.clixoo.com/purchase/oilgae/alg_pdt/report.html (accessed on 27 January 2018).

80. Minhas, A.K.; Hodgson, P.; Barrow, C.J.; Adholeya, A. A review on the assessment of stress conditions for simultaneous production of microalgal lipids and carotenoids. Front. Microbiol. 2016, 7, 546. [CrossRef]

81. Coesel, S.N.; Baumgartner, A.C.; Teles, L.M.; Ramos, A.A.; Henriques, N.M.; Cancela, L.; Varela, J.C.S. Nutrient limitation is the main regulatory factor for carotenoid accumulation and for Psy and Pds steady state transcript levels in Dunaliella salina (Chlorophyta) exposed to high light and salt stress. Mar. Biotechnol. 2008, 10, 602-611. [CrossRef]

82. Shah, M.M.R.; Liang, Y.; Cheng, J.J.; Daroch, M. Astaxanthin-producing green microalga Haematococcus pluvialis: From single cell to high value commercial products. Front. Plant Sci. 2016, 7, 531. [CrossRef] 
83. Ryckebosch, E.; Bruneel, C.; Termote-Verhalle, R.; Goiris, K.; Muylaert, K.; Foubert, I. Nutritional evaluation of microalgae oils rich in omega-3 long chain polyunsaturated fatty acids as an alternative for fish oil. Food Chem. 2014, 160, 393-400. [CrossRef]

84. Gerber, L.R.; Karimi, R.; Fitzgerald, T.P. Sustaining seafood for public health. Front. Ecol. Environ. 2012, 10, 487-493. [CrossRef]

85. Adarme-Vega, T.C.; Thomas-Hall, S.R.; Lim, D.K.; Schenk, P.M. Effects of long chain fatty acid synthesis and associated gene expression in microalga Tetraselmis sp. Mar. Drugs 2014, 12, 3381-3398. [CrossRef]

86. Nauroth, J.M.; Liu, Y.C.; Van Elswyk, M.; Bell, R.; Hall, E.B.; Chung, G.; Arterburn, L.M. Docosahexaenoic Acid (DHA) and Docosapentaenoic Acid (DPAn-6) Algal Oils Reduce Inflammatory Mediators in Human Peripheral Mononuclear Cells In vitro and Paw Edema In vivo. Lipids 2010, 45, 375-384. [CrossRef]

87. Wynn, J.P.; Ratledge, C. Oils from Microorganisms. In Bailey's Industrial Oil and Fat Products; Shahidi, F., Ed.; John Wiley \& Sons: Hoboken, NJ, USA, 2005.

88. Martek Biosciences Corporation Annual Report. 2007. Available online: http://library.corporate-ir.net/library/ 11/116/116214/items/281192/MATK_2007_Annual.pdf (accessed on 25 February 2018).

89. Fujitani, N.; Sakaki, S.; Yamaguchi, Y.; Takenaka, H. Inhibitory effects of microalgae on the activation of hyaluronidase. J. Appl. Phycol. 2001, 13, 489-492. [CrossRef]

90. Borowitzka, M.A. Microalgae as sources of pharmaceuticals and other biologically active compounds. J. Appl. Phycol. 1995, 7, 3-15. [CrossRef]

91. Ciccone, M.M.; Cortese, F.; Gesualdo, M.; Carbonara, S.; Zito, A.; Ricci, G.; De Pascalis, F.; Scicchitano, P.; Riccioni, G. Dietary intake of carotenoids and their antioxidant and anti-inflammatory effects in cardiovascular care. Mediat. Inflamm. 2013, 2013, 782137. [CrossRef]

92. Del Campo, J.A.; Rodriguez, H.; Moreno, J.; Vargas, M.A.; Rivas, J.; Guerrero, M.G. Lutein production by Muriellopsis sp. in an outdoor tubular photobioreactor. J. Biotechnol. 2001, 85, 289-295. [CrossRef]

93. Sánchez, J.F.; Fernández-Sevilla, J.M.; Acién, F.G.; Cerón, M.C.; Pérez-Parra, J.; Molina-Grima, E. Biomass and lutein productivity of Scenedesmus almeriensis: Influence of irradiance, dilution rate and temperature. Appl. Microbiol. Biotechnol. 2008, 79, 719-729. [CrossRef]

94. Cordero, B.F.; Obraztsova, I.; Couso, I.; Leon, R.; Vargas, M.A.; Rodriguez, H. Enhancement of lutein production in Chlorella sorokiniana (Chorophyta) by improvement of culture conditions and random mutagenesis. Mar. Drugs 2011, 9, 1607-1624. [CrossRef]

95. Su, G.; Jiao, K.; Chang, J.; Li, Z.; Guo, X.; Sun, Y.; Zeng, X.; Lu, Y.; Lin, L. Enhancing total fatty acids and arachidonic acid production by the red microalgae Porphyridium purpureum. Bioresources Bioprocess. 2016, 3, 33. [CrossRef]

96. Solovchenko, A.E.; Khozin-Goldberg, I.; Didi-Cohen, S.; Cohen, Z.; Merzlyak, M.N. Effects of light intensity and nitrogen starvation on growth, total fatty acids and arachidonic acid in the green microalga Parietochloris incisa. J. Appl. Phycol. 2008, 20, 245-251. [CrossRef]

97. Giménez, A.G.; González, M.I.; Medina, A.R.; Grima, E.M.; Salas, S.G.; Cerdán, L.E. Downstream processing and purification of eicosapentaenoic (20: $5 n-3)$ and arachidonic acids (20: $4 n-6)$ from the microalga Porphyridium cruentum. Bioseparation 1998, 7, 89-99. [CrossRef]

98. Asgharpour, M.; Rodgers, B.; Hestekin, J.A. Eicosapentaenoic acid from Porphyridium Cruentum: Increasing growth and productivity of microalgae for pharmaceutical products. Energies 2015, 8, 10487-10503. [CrossRef]

99. Molina Grima, E.; Garcia Camacho, F.; Ácien Fernandez, F.G. Production of EPA from Phaeodactylum tricornutum. In Chemicals from Microalgae; Cohen, Z., Ed.; Taylor \& Francis: London, UK, 1999; pp. 57-92.

100. Sukenik, A. Production of eicosapentaenoic acid by the marine eustigmatophyte Nannochloropsis. In Chemicals from Microalgae; Cohen, Z., Ed.; Taylor \& Francis: London, UK, 1999; pp. 41-56.

101. Chu, W.L. Biotechnological applications of microalgae. IeJSME 2012, 6, S24-S37.

102. Horrocks, L.A.; Yeo, Y.K. Health benefits of docosahexaenoic acid (DHA). Pharmacol. Res. 1999, 40, $211-225$. [CrossRef]

103. Wang, X.; Zhang, X. Separation, antitumor activities, and encapsulation of polypeptide from Chlorella pyrenoidosa. Biotechnol. Prog. 2013, 29, 681-687. [CrossRef]

104. Samarakoon, K.W.; Kwon, O.N.; Ko, J.Y.; Lee, J.H.; Kang, M.C.; Kim, D.; Lee, J.B.; Lee, J.S.; Jeon, Y.J. Purification and identification of novel angiotensin-I converting enzyme (ACE) inhibitory peptides from cultured marine microalgae (Nannochloropsis oculata) protein hydrolysate. J. Appl. Phycol. 2013, 25, 1595-1606. [CrossRef] 
105. Cha, T.S.; Chen, C.F.; Yee, W.; Aziz, A.; Loh, S.H. Cinnamic acid, coumarin and vanillin: Alternative phenolic compounds for efficient Agrobacterium-mediated transformation of the unicellular green alga, Nannochloropsis sp. J. Microbiol. Meth. 2011, 84, 430-434. [CrossRef]

106. El-Baky, H.H.A.; El Baz, F.K.; El-Baroty, G.S. Production of phenolic compounds from Spirulina maxima microalgae and its protective effects in vitro toward hepatotoxicity model. Afr. J. Pharm. Pharmacol. 2009, 3, 133-139.

107. Romay, C.H.; Gonzalez, R.; Ledon, N.; Remirez, D.; Rimbau, V. C-phycocyanin: A biliprotein with antioxidant, anti-inflammatory and neuroprotective effects. Curr. Protein Pept. Sci. 2003, 4, 207-216. [CrossRef]

108. Guzman, S.; Gato, A.; Lamela, M.; Freire-Garabal, M.; Calleja, J.M. Anti-inflammatory and immunomodulatory activities of polysaccharide from Chlorella stigmatophora and Phaeodactylum tricornutum. Phytother. Res. 2003, 17, 665-670. [CrossRef]

109. Huheihel, M.; Ishanu, V.; Tal, J.; Arad, S.M. Activity of Porphyridium sp. polysaccharide against herpes simplex viruses in vitro and in vivo. J. Biochem. Biophys. Methods 2002, 50, 189-200. [CrossRef]

110. Tannin-Spitz, T.; Bergman, M.; van-Moppes, D.; Grossman, S.; Arad, S.M. Antioxidant activity of the polysaccharide of the red microalga Porphyridium sp. J. Appl. Phycol. 2005, 17, 215-222. [CrossRef]

111. Trabelsi, L.; Chaieb, O.; Mnari, A.; Abid-Essafi, S.; Aleya, L. Partial characterization and antioxidant and antiproliferative activities of the aqueous extracellular polysaccharides from the thermophilic microalgae Graesiella sp. BMC Complement. Altern. Med. 2016, 16, 210. [CrossRef]

112. Zhu, L. Biorefinery as a promising approach to promote microalgae industry: An innovative framework. Renew. Sustain. Energy Rev. 2015, 41, 1376-1384. [CrossRef]

113. Greenwell, H.C.; Laurens, L.M.L.; Shields, R.J.; Lovitt, R.W.; Flynn, K.J. Placing microalgae on the biofuels priority list: A review of the technological challenges. J. R. Soc. Interface 2009, 7, 703-726. [CrossRef]

114. Potumarthi, R.; Baadhe, R.R. Issues in algal biofuels for fuelling the future. In Applications of Microbial Engineering; Gupta, V.K., Schmoll, M., Maki, M., Tuohy, M., Mazutti, M.A., Eds.; CRC Press: Boca Raton, FL, USA, 2013; pp. 408-425.

115. Ruiz, J.; Olivieri, G.; de Vree, J.; Bosma, R.; Willems, P.; Reith, J.H.; Eppink, M.H.; Kleinegris, D.M.; Wijffels, R.H.; Barbosa, M.J. Towards industrial products from microalgae. Energy Environ. Sci. 2016, 9, 3036-3043. [CrossRef]

116. Padmanabhan, $\mathrm{P}$. Technical insight on the requirements for $\mathrm{CO}_{2}$-saturated growth of microalgae in photobioreactors. 3 Biotech 2017, 7, 119.

117. Torzillo, G.; Accolla, P.; Pinzani, E.; Masojidek, J. In situ monitoring of chlorophyll fluorescence to assess the synergistic effect of low temperature and high irradiance stresses in Spirulina cultures grown outdoors in photobioreactors. J. Appl. Phycol. 1996, 8, 283-291. [CrossRef]

118. Richmond, A.; Boussiba, S.; Vonshak, A.; Kopel, R. A new tubular reactor for mass production of microalgae outdoors. J. Appl. Phycol. 1993, 5, 327-332. [CrossRef]

119. Ying, K.; Gilmour, D.J.; Zimmerman, W.B. Effects of $\mathrm{CO}_{2}$ and $\mathrm{pH}$ on growth of the microalga Dunaliella salina. J. Microb. Biochem. Technol. 2014, 6, 167-173. [CrossRef]

120. Mallick, N.; Bagchi, S.K.; Koley, S.; Singh, A.K. Progress and challenges in microalgal biodiesel production. Front. Microbiol. 2016, 7, 1019. [CrossRef]

121. Maranon, E. Phytoplankton growth rates in the Atlantic subtropical gyres. Limnol. Oceanogr. 2005, 50, $299-310$. [CrossRef]

122. Chisti, Y. Raceways-based production of algal crude oil. In Microalgal Biotechnology: Potential and Production; Posten, C., Walter, C., Eds.; de Gruyter: Berlin, Germany, 2012; pp. 113-146.

123. Jovine, R. Method of Culturing Algae. U.S. Patent 20130269244A1, 17 October 2013.

124. Geider, R.J.; Osborne, B.A. Respiration and microalgal growth: A review of the quantitative relationship between dark respiration and growth. New Phytol. 1989, 112, 327-341. [CrossRef]

125. Grobbelaar, J.U.; Soeder, C.J. Respiration losses in planktonic green algae cultivated in raceway ponds. J. Plankton Res. 1985, 7, 497-506. [CrossRef]

126. Huesemann, M.; Crowe, B.; Waller, P.; Chavis, A.; Hobbs, S.; Edmundson, S.; Wigmosta, M. A validated model to predict microalgae growth in outdoor pond cultures subjected to fluctuating light intensities and water temperatures. Algal Res. 2016, 13, 195-206. [CrossRef]

127. Günerken, E.; d'Hondt, E.; Eppink, M.H.M.; Garcia-Gonzalez, L.; Elst, K.; Wijffels, R.H. Cell disruption for microalgae biorefineries. Biotechnol. Adv. 2015, 33, 243-260. [CrossRef] 
128. Amaro, H.M.; Fernandes, F.; Valentão, P.; Andrade, P.B.; Sousa-Pinto, I.; Malcata, F.X.; Guedes, A. Effect of solvent system on extractability of lipidic components of Scenedesmus obliquus (M2-1) and Gloeothece sp. on antioxidant scavenging capacity thereof. Mar. Drugs 2015, 13, 6453-6471. [CrossRef] [PubMed]

129. Foo, S.C.; Yusoff, F.M.; Ismail, M.; Basri, M.; Chan, K.W.; Khong, N.M.; Yau, S.K. Production of fucoxanthin-rich fraction (FxRF) from a diatom, Chaetoceros calcitrans (Paulsen) Takano 1968. Algal Res. 2015, 12, $26-32$. [CrossRef]

130. Ventura, S.P.M.; Nobre, B.P.; Ertekin, F.; Hayes, M.; Garcia'-Vaquero, M.; Vieira, F.; Koc, M.; Gouveia, L.; Aires-Barros, M.R.; Palavra, A.M.F. Extraction of value-added compounds from microalgae. In Microalgae-Based Biofuels and Bioproducts: From Feedstock Cultivation to End-Products; Gonalez-Fernandez, C., Munoz, R., Eds.; Woodhead Publishing: Sawston, UK, 2017; pp. 461-483.

131. Lee, J.Y.; Yoo, C.; Jun, S.Y.; Ahn, C.Y.; Oh, H.M. Comparison of several methods for effective lipid extraction from microalgae. Bioresource Technol. 2010, 101, S75-S77. [CrossRef]

132. dos Santos, R.R.; Moreira, D.M.; Kunigami, C.N.; Aranda, D.A.G.; Teixeira, C.M.L.L. Comparison between several methods of total lipid extraction from Chlorella vulgaris biomass. Ultrason. Sonochem. 2015, 22, 95-99. [CrossRef]

133. Ryckebosch, E.; Muylaert, K.; Foubert, I. Optimization of an analytical procedure for extraction of lipids from microalgae. J. Am. Oil Chem. Soc. 2012, 89, 189-198. [CrossRef]

134. Wynn, J.; Behrens, P.; Sundararajan, A.; Hansen, J.; Apt, K. Production of single cell oils by dinoflagellates. In Single Cell Oils, 2nd ed.; Cohen, Z., Ratledge, C., Eds.; AOCS Press: Urbana, IL, USA, 2010; pp. 115-129.

135. Ward, O.P.; Singh, A. Omega-3/6 fatty acids: Alternative sources of production. Process Biochem. 2005, 40,3627-3652. [CrossRef]

136. Wieczorek, P.P.; Lipok, J.; Górka, B. Biologically active compounds isolated from algae and their application as a plant growth regulators. In Proceedings of the IX International Scientific Conference daRostim, Lviv, Ukraine, 7-10 October 2013.

137. Zhang, Z.S.; Wang, F.; Wang, X.M.; Liu, X.L.; Hou, Y.; Zhang, Q.B. Extraction of the polysaccharides from five algae and their potential antioxidant activity in vitro. Carbohydr. Polym. 2010, 82, 118-121. [CrossRef]

138. Xu, S.Y.; Huang, X.; Cheong, K.L. Recent advances in marine algae polysaccharides: Isolation, structure, and activities. Mar. Drugs 2017, 15, 388. [CrossRef]

139. Yuan, Y.; Macquarrie, D. Microwave assisted extraction of sulfated polysaccharides (fucoidan) from Ascophyllum nodosum and its antioxidant activity. Carbohydr. Polym. 2015, 129, 101-107. [CrossRef]

140. Tsubaki, S.; Oono, K.; Hiraoka, M.; Onda, A.; Mitani, T. Microwave-assisted hydrothermal extraction of sulfated polysaccharides from Ulva spp. and Monostroma latissimum. Food Chem. 2016, 2103, 11-316. [CrossRef]

141. Rahimi, F.; Tabarsa, M.; Rezaei, M. Ulvan from green algae Ulva intestinalis: Optimization of ultrasound-assisted extraction and antioxidant activity. J. Appl. Phycol. 2016, 28, 2979-2990. [CrossRef]

142. Tang, W.; Lin, L.H.; Xie, J.H.; Wang, Z.; Wang, H.J.; Dong, Y.J.; Shen, M.Y.; Xie, M.Y. Effect of ultrasonic treatment on the physicochemical properties and antioxidant activities of polysaccharide from Cyclocarya paliurus. Carbohydr. Polym. 2016, 151, 305-312. [CrossRef]

143. Lim, S.J.; Aida, W.M.W.; Maskat, M.T.; Mamot, S.; Ropien, J.; Mohd, D.M. Isolation and antioxidant capacity of fucoidan from selected Malaysian seaweeds. Food Hydrocoll. 2014, 42, 280-288. [CrossRef]

144. Nasri, M. Protein hydrolysates and biopeptides: Production, biological activities, and applications in foods and health benefits: A review. Adv. Food Nutr. Res. 2017, 81, 109-159.

145. Thorkelsson, G.; Sigurgisladottir, S.; Geirsdottir, M.; Jóhannsson, R.; Guerard, F.; Chabeaud, A.; Bourseau, P.; Vandanjon, L.; Jaouen, P.; Chaplain-Derouiniot, M.; et al. Mild processing techniques and development of functional marine protein and peptide ingredients. In Improving Seafood Products for the Consumer; Borresen, T., Ed.; Woodhead: Cambridge, UK, 2008; p. 612.

146. Clemente, A. Enzymatic protein hydrolysates in human nutrition. Trends Food Sci. Technol. 2000, 11, $254-262$. [CrossRef]

147. Gao, M.T.; Hirata, M.; Toorisaka, E.; Hano, T. Acid-hydrolysis of fish wastes for lactic acid fermentation. Bioresource Technol. 2006, 97, 2414-2420. [CrossRef]

148. Kim, S.K.; Wijesekara, I. Development and Biological Activities of Marine-Derived Bioactive Peptides: A Review. J. Funct. Food 2010, 2, 1-9. [CrossRef] 
149. Nasri, R.; Chataigné, G.; Bougatef, A.; Chaâbouni, M.K.; Dhulster, P.; Nasri, M.; Nedjar-Arroume, N. Novel angiotensin I-converting enzyme inhibitory peptides from enzymatic hydrolysates of goby (Zosterisessor ophiocephalus) muscle proteins. J. Proteomics 2013, 91, 444-452. [CrossRef]

150. Wijesekara, I.; Qian, Z.J.; Ryu, B.; Ngo, D.H.; Kim, S.K. Purification and identification of antihypertensive peptides from seaweed pipefish (Syngnathus schlegeli) muscle protein hydrolysate. Food Res. Int. 2011, 44, 703-707. [CrossRef]

151. Maehre, H.K.; Edvinsen, G.K.; Eilertsen, K.E.; Elvevoll, E.O. Heat treatment increases the protein bioaccessibility in the red seaweed dulse (Palmaria palmata), but not in the brown seaweed winged kelp (Alaria esculenta). J. Appl. Phycol. 2016, 28, 581-590. [CrossRef]

152. Waghmare, A.G.; Salve, M.K.; LeBlanc, J.G.; Arya, S.S. Concentration and characterization of microalgae proteins from Chlorella pyrenoidosa. Bioresources Bioprocess. 2016, 3, 16. [CrossRef]

153. Ferreira, I.M.P.L.V.; Eça, R.; Pinho, O.; Tavares, P.; Pereira, A.; Cecília Roque, A. Development and validation of an HPLC/UV method for quantification of bioactive peptides in fermented milks. J. Liq. Chromatogr. Relat. Technol. 2007, 30, 2139-2147. [CrossRef]

154. Majors, R.E. Developments in preparative-scale chromatography. LC•GC Eur. 2004, 17, 630-638.

155. Bargeman, G.; Koops, G.H.; Houwing, J.; Breebaart, I.; Van der Horst, H.C.; Wessling, M. The development of electro-membrane filtration for the isolation of bioactive peptides: The effect of membrane selection and operating parameters on the transport rate. Desalination 2002, 149, 369-374. [CrossRef]

156. Sun, L.; Wu, S.; Zhou, L.; Wang, F.; Lan, X.; Sun, J.; Tong, Z.; Liao, D. Separation and Characterization of Angiotensin I Converting Enzyme (ACE) Inhibitory Peptides from Saurida elongata Proteins Hydrolysate by IMAC-Ni2+. Mar. Drugs 2017, 15, 29. [CrossRef]

157. Andersson, L.; Blomberg, L.; Flegel, M.; Lepsa, L.; Nilsson, B.; Verlander, M. Large-scale synthesis of peptides. Pept. Sci. 2000, 55, 227-250. [CrossRef]

158. Agyei, D.; Ongkudon, C.M.; Wei, C.Y.; Chan, A.S.; Danquah, M.K. Bioprocess challenges to the isolation and purification of bioactive peptides. Food Bioprod. Process. 2016, 98, 244-256. [CrossRef]

159. Rietjens, I.M.; Boersma, M.G.; de Haan, L.; Spenkelink, B.; Awad, H.M.; Cnubben, N.H.; van Zanden, J.J.; van der Woude, H.; Alink, G.M.; Koeman, J.H. The pro-oxidant chemistry of the natural antioxidants vitamin C, vitamin E, carotenoids and flavonoids. Environ. Toxicol. Pharmacol. 2002, 11, 321-333. [CrossRef]

160. Xia, S.; Wang, K.; Wan, L.; Li, A.; Hu, Q.; Zhang, C. Production, characterization, and antioxidant activity of fucoxanthin from the marine diatom Odontella aurita. Mar. Drugs 2013, 11, 2667-2681. [CrossRef]

161. Goiris, K.; Van Colen, W.; Wilches, I.; León-Tamariz, F.; De Cooman, L.; Muylaert, K. Impact of nutrient stress on antioxidant production in three species of microalgae. Algal Res 2015, 7, 51-57. [CrossRef]

162. Halliwell, B. Oxidative stress and neurodegeneration: Where are we now? J. Neurochem. 2006, 97, 1634-1658. [CrossRef]

163. Gülçin, I. Antioxidant activity of food constituents: An overview. Arch. Toxicol. 2012, 86, 345-391. [CrossRef]

164. Pietta, P.G. Flavonoids as antioxidants. J. Nat. Prod 2000, 63, 1035-1042. [CrossRef]

165. Gülçin, İ; Elias, R.; Gepdiremen, A.; Boyer, L. Antioxidant activity of lignans from fringe tree (Chionanthus virginicus L.). Eur. Food Res. Technol. 2006, 223, 759. [CrossRef]

166. Halliwell, B.; Gutteridge, J.M. Free Radicals in Biology and Medicine; Oxford University Press: Oxford, MA, USA, 2015.

167. Marks, D.B.; Marks, A.D.; Smith, C.M. Oxygen metabolism and toxicity. In Basic Medical Biochemistry: A Clinical Approach; Williams and Wilkins: Baltimore, MD, USA, 1996; pp. 327-340.

168. Reed, D.J. Toxicity of oxygen. In Molecular and Cellular Mechanisms of Toxicity; De Matteis, F., Smith, L.L., Eds.; CRC Press: Boca Raton, FL, USA, 1995; pp. 35-68.

169. Pashkow, F.J. Oxidative stress and inflammation in heart disease: Do antioxidants have a role in treatment and/or prevention? Int. J. Inflamm. 2011. [CrossRef]

170. Larkum, A.W.; Kühl, M. Chlorophyll d: The puzzle resolved. Trends Plant Sci. 2005, 10, 355-357. [CrossRef]

171. Ioannou, E.; Roussis, V. Natural products from seaweeds. In Plant-Derived Natural Products; Springer: New York, NY, USA, 2009; pp. 51-81.

172. Stahl, W.; Sies, H. Antioxidant activity of carotenoids. Mol. Aspects Med. 2003, 24, 345-351. [CrossRef]

173. de Jesus Raposo, M.F.; de Morais, A.M.M.B.; de Morais, R.M.S.C. Carotenoids from marine microalgae: A valuable natural source for the prevention of chronic diseases. Mar. Drugs 2015, 13, 5128-5155. [CrossRef] 
174. Blas-Valdivia, V.; Ortiz-Butron, R.; Rodriguez-Sanchez, R.; Torres-Manzo, P.; Hernandez-Garcia, A.; Cano-Europa, E. Microalgae of the Chlorophyceae Class: Potential Nutraceuticals Reducing Oxidative Stress Intensity and Cellular Damage. Mar. Drugs 2014, 12, 4883-4897.

175. Sachindra, N.M.; Sato, E.; Maeda, H.; Hosokawa, M.; Niwano, Y.; Kohno, M.; Miyashita, K. Radical scavenging and singlet oxygen quenching activity of marine carotenoid fucoxanthin and its metabolites. $J$. Agric. Food Chem. 2007, 55, 8516-8522. [CrossRef]

176. Klejdus, B.; Lojková, L.; Plaza, M.; Šnóblová, M.; Štěrbová, D. Hyphenated technique for the extraction and determination of isoflavones in algae: Ultrasound-assisted supercritical fluid extraction followed by fast chromatography with tandem mass spectrometry. J. Chromatogr. A 2010, 1217, 7956-7965. [CrossRef]

177. Pan, M.H.; Lai, C.S.; Ho, C.T. Anti-inflammatory activity of natural dietary flavonoids. Food Funct. 2010, 1, 15-31. [CrossRef]

178. Chaudhuri, D.; Ghate, N.B.; Deb, S.; Panja, S.; Sarkar, R.; Rout, J.; Mandal, N. Assessment of the phytochemical constituents and antioxidant activity of a bloom forming microalgae Euglena tuba. Biol. Res. 2014, 47, 24. [CrossRef]

179. Custódio, L.; Justo, T.; Silvestre, L.; Barradas, A.; Duarte, C.V.; Pereira, H.; Barreira, L.; Rauter, A.P.; Alberício, F.; Varela, J. Microalgae of different phyla display antioxidant, metal chelating and acetylcholinesterase inhibitory activities. Food Chem. 2012, 131, 134-140. [CrossRef]

180. Geetha, B.V.; Rajendran, N.; Ekambaram, P. Investigation of antioxidant capacity and phytochemical composition of Sun Chlorella-an in vitro study. J. Aquac. Res. Dev. 2010, 1, 104. [CrossRef]

181. Bravo, L. Polyphenols: Chemistry, dietary sources, metabolism, and nutritional significance. Nutr. Rev. 1998, 56, 317-333. [CrossRef]

182. Manivannan, K.; Anantharaman, P.; Balasubramanian, T. Evaluation of antioxidant properties of marine microalga Chlorella marina (Butcher, 1952). Asian Pac. J. Trop. Biomed. 2012, 2, S342-S346. [CrossRef]

183. Li, H.B.; Cheng, K.W.; Wong, C.C.; Fan, K.W.; Chen, F.; Jiang, Y. Evaluation of antioxidant capacity and total phenolic content of different fractions of selected microalgae. Food Chem. 2007, 102, 771-776. [CrossRef]

184. Cos, P.; Ying, L.; Calomme, M.; Hu, J.P.; Cimanga, K.; Van Poel, B.; Pieters, L.; Vlietinck, A.J.; Berghe, D.V. Structure-activity relationship and classification of flavonoids as inhibitors of xanthine oxidase and superoxide scavengers. J. Nat. Prod. 1998, 61, 71-76. [CrossRef]

185. Machu, L.; Misurcova, L.; Vavra Ambrozova, J.; Orsavova, J.; Mlcek, J.; Sochor, J.; Jurikova, T. Phenolic content and antioxidant capacity in algal food products. Molecules 2015, 20, 1118-1133. [CrossRef]

186. Hajimahmoodi, M.; Faramarzi, M.A.; Mohammadi, N.; Soltani, N.; Oveisi, M.R.; Nafissi-Varcheh, N. Evaluation of antioxidant properties and total phenolic contents of some strains of microalgae. J. Appl. Phycol. 2010, 22, 43-50. [CrossRef]

187. Norzagaray-Valenzuela, C.D.; Valdez-Ortiz, A.; Shelton, L.M.; Jiménez-Edeza, M.; Rivera-López, J.; Valdez-Flores, M.A.; Germán-Báez, L.J. Residual biomasses and protein hydrolysates of three green microalgae species exhibit antioxidant and anti-aging activity. J. Appl. Phycol. 2016, 29, 189-198. [CrossRef]

188. Maadane, A.; Merghoub, N.; Ainane, T.; El Arroussi, H.; Benhima, R.; Amzazi, S.; Bakri, Y.; Wahby, I. Antioxidant activity of some Moroccan marine microalgae: Pufa profiles, carotenoids and phenolic content. J. Biotechnol. 2015, 215, 13-19. [CrossRef]

189. Cha, K.H.; Kang, S.W.; Kim, C.Y.; Um, B.H.; Na, Y.R.; Pan, C.H. Effect of pressurized liquids on extraction of antioxidants from Chlorella vulgaris. J. Agric. Food Chem. 2010, 58, 4756-4761. [CrossRef]

190. Jerez-Martel, I.; García-Poza, S.; Rodríguez-Martel, G.; Rico, M.; Afonso-Olivares, C.; Gómez-Pinchetti, J.L. Phenolic profile and antioxidant activity of crude extracts from microalgae and cyanobacteria strains. J. Food Qual. 2017. [CrossRef]

191. Klejdus, B.; Kopecký, J.; Benešová, L.; Vacek, J. Solid-phase/supercritical-fluid extraction for liquid chromatography of phenolic compounds in freshwater microalgae and selected cyanobacterial species. J. Chromatogr. A 2009, 1216, 763-771. [CrossRef]

192. Poljsak, B.; Milisav, I. The neglected significance of "antioxidative stress". Oxid. Med. Cell. Longev. 2012, 2012. [CrossRef]

193. Ejike, C.E.; Collins, S.A.; Balasuriya, N.; Swanson, A.K.; Mason, B.; Udenigwe, C.C. Prospects of microalgae proteins in producing peptide-based functional foods for promoting cardiovascular health. Trends Food Sci. Technol. 2017, 59, 30-36. [CrossRef] 
194. Sánchez, A.; Vázquez, A. Bioactive peptides: A review. Food Qual. Saf. 2017, 1, 29-46. [CrossRef]

195. Lemes, A.C.; Sala, L.; Ores, J.D.C.; Braga, A.R.C.; Egea, M.B.; Fernandes, K.F. A review of the latest advances in encrypted bioactive peptides from protein-rich waste. Int. J. Mol. Sci. 2016, 17, 950. [CrossRef]

196. Ngo, D.H.; Vo, T.S.; Ngo, D.N.; Wijesekara, I.; Kim, S.K. Biological activities and potential health benefits of bioactive peptides derived from marine organisms. Int. J. Biol. Macromol. 2012, 51, 378-383. [CrossRef]

197. Maestri, E.; Marmiroli, M.; Marmiroli, N. Bioactive peptides in plant-derived foodstuffs. J. Proteomics 2016, 147, 140-155. [CrossRef]

198. Alzahrani, M.A.J.; Perera, C.O.; Hemar, Y. Production of bioactive proteins and peptides from the diatom Nitzschia laevis and comparison of their in vitro antioxidant activities with those from Spirulina platensis and Chlorella vulgaris. Int. J. Food Sci. Technol. 2018, 53, 676-682. [CrossRef]

199. García, M.C.; Puchalska, P.; Esteve, C.; Marina, M.L. Vegetable foods: A cheap source of proteins and peptides with antihypertensive, antioxidant, and other less occurrence bioactivities. Talanta 2013, 106, 328-349. [CrossRef]

200. Alam, M.N.; Bristi, N.J.; Rafiquzzaman, M. Review on in vivo and in vitro methods evaluation of antioxidant activity. Saudi Pharm. J. 2013, 21, 143-152. [CrossRef]

201. Shih, M.F.; Cherng, J.Y. Protective effects of Chlorella-derived peptide against UVC-induced cytotoxicity through inhibition of caspase-3 activity and reduction of the expression of phosphorylated FADD and cleaved PARP-1 in skin fibroblasts. Molecules 2012, 17, 9116-9128. [CrossRef]

202. Lee, S.H.; Chang, D.U.; Lee, B.J.; Jeon, Y.J. Antioxidant activity of solubilized Tetraselmis suecica and Chlorella ellipsoidea by enzymatic digests. J. Food Sci. Nutr. 2009, 14, 21-28. [CrossRef]

203. Ko, S.C.; Kim, D.; Jeon, Y.J. Protective effect of a novel antioxidative peptide purified from a marine Chlorella ellipsoidea protein against free radical-induced oxidative stress. Food Chem. Toxicol. 2012, 50, 2294-2302. [CrossRef]

204. Sheih, I.C.; Wu, T.K.; Fang, T.J. Antioxidant properties of a new antioxidative peptide from algae protein waste hydrolysate in different oxidation systems. Bioresource Technol. 2009, 100, 3419-3425. [CrossRef] [PubMed]

205. Kang, K.H.; Qian, Z.J.; Ryu, B.; Karadeniz, F.; Kim, D.; Kim, S.K. Antioxidant peptides from protein hydrolysate of microalgae Navicula incerta and their protective effects in HepG2/CYP2E1 cells induced by ethanol. Phytother. Res. 2012, 26, 1555-1563. [CrossRef] [PubMed]

206. Zou, T.B.; He, T.P.; Li, H.B.; Tang, H.W.; Xia, E.Q. The structure-activity relationship of the antioxidant peptides from natural proteins. Molecules 2016, 21, 72. [CrossRef] [PubMed]

207. Tian, M.; Fang, B.; Jiang, L.; Guo, H.; Cui, J.; Ren, F. Structure-activity relationship of a series of antioxidant tripeptides derived from $\beta$-Lactoglobulin using QSAR modeling. Dairy Sci. Technol. 2015, 95, 451-463. [CrossRef]

208. Samaranayaka, A.G.; Li-Chan, E.C. Food-derived peptidic antioxidants: A review of their production, assessment, and potential applications. J. Funct Food 2011, 3, 229-254. [CrossRef]

209. Li, Y.W.; Li, B. Characterization of structure-antioxidant activity relationship of peptides in free radical systems using QSAR models: Key sequence positions and their amino acid properties. J. Theor Biol. 2013, 318, 29-43. [CrossRef] [PubMed]

210. WHO [World Health Organization]. Global Status Report on Noncommunicable Diseases; WHO: Geneve, Switzerland, 2014; p. 176.

211. Melaku, L.; Mossie, A. Cardioprotective effects of angiotensin converting Enzyme II. Int. J. Clin. Exp. Physiol. 2017, 4, 57.

212. Muñoz-Durango, N.; Fuentes, C.A.; Castillo, A.E.; González-Gómez, L.M.; Vecchiola, A.; Fardella, C.E.; Kalergis, A.M. Role of the renin-angiotensin-aldosterone system beyond blood pressure regulation: Molecular and cellular mechanisms involved in end-organ damage during arterial hypertension. Int. J Mol. Sci. 2016, 17, 797. [CrossRef] [PubMed]

213. Murohara, T.; Buerke, M.; Lefer, A.M. Polymorphonuclear leukocyte-induced vasocontraction and endothelial dysfunction. Role of selectins. Arterioscler. Thromb. J. Vasc. Biol. 1994, 14, 1509-1519. [CrossRef]

214. Majumder, $\mathrm{K}$; $\mathrm{Wu}, \mathrm{J}$. Molecular targets of antihypertensive peptides: Understanding the mechanisms of action based on the pathophysiology of hypertension. Int. J. Mol. Sci. 2014, 16, 256-283. [CrossRef] 
215. Solomon, S.D.; Skali, H.; Bourgoun, M.; Fang, J.; Ghali, J.K.; Martelet, M.; Wojciechowski, D.; Ansmite, B.; Skards, J.; Laks, T.; et al. Effect of angiotensin-converting enzyme or vasopeptidase inhibition on ventricular size and function in patients with heart failure: The Omapatrilat Versus Enalapril Randomized Trial of Utility in Reducing Events (OVERTURE) echocardiographic study. Am. Heart J. 2005, 150, 257-262. [CrossRef] [PubMed]

216. Daemen, M.J.; Lombardi, D.M.; Bosman, F.T.; Schwartz, S.M. Angiotensin II induces smooth muscle cell proliferation in the normal and injured rat arterial wall. Circ. Res. 1991, 68, 450-456. [CrossRef]

217. Norris, R.; FitzGerald, R.J. Antihypertensive peptides from food proteins. In Bioactive Food Peptides in Health and Disease; Hernandez-Ledesma, B., Hsieh, C.C., Eds.; InTech: London, UK, 2013; pp. 45-72.

218. Girgih, A.T.; Alashi, A.; He, R.; Malomo, S.; Aluko, R.E. Preventive and treatment effects of a hemp seed (Cannabis sativa L.) meal protein hydrolysate against high blood pressure in spontaneously hypertensive rats. Eur. J. Nutr. 2014, 53, 1237-1246. [CrossRef] [PubMed]

219. Majumder, K.; Chakrabarti, S.; Morton, J.S.; Panahi, S.; Kaufman, S.; Davidge, S.T.; Wu, J. Egg-derived tri-peptide IRW exerts antihypertensive effects in spontaneously hypertensive rats. PLoS ONE 2013, 8, e82829. [CrossRef] [PubMed]

220. Fernández-Musoles, R.; Manzanares, P.; Burguete, M.C.; Alborch, E.; Salom, J.B. In vivo angiotensin I-converting enzyme inhibition by long-term intake of antihypertensive lactoferrin hydrolysate in spontaneously hypertensive rats. Food Res. Int. 2013, 54, 627-632. [CrossRef]

221. Murray, B.A.; FitzGerald, R.J. Angiotensin converting enzyme inhibitory peptides derived from food proteins: Biochemistry, bioactivity and production. Curr. Pharm. Des. 2007, 13, 773-791. [CrossRef]

222. Sheih, I.C.; Fang, T.J.; Wu, T.K. Isolation and characterisation of a novel angiotensin I-converting enzyme (ACE) inhibitory peptide from the algae protein waste. Food Chem. 2009, 115, 279-284. [CrossRef]

223. Ko, S.C.; Kang, N.; Kim, E.A.; Kang, M.C.; Lee, S.H.; Kang, S.M.; Lee, J.B.; Jeon, B.T.; Kim, S.K.; Park, S.J.; et al. A novel angiotensin I-converting enzyme (ACE) inhibitory peptide from a marine Chlorella ellipsoidea and its antihypertensive effect in spontaneously hypertensive rats. Process Biochem. 2012, 47, 2005-2011. [CrossRef]

224. Udenigwe, C.C.; Aluko, R.E. Food protein-derived bioactive peptides: Production, processing, and potential health benefits. J. Food Sci. 2012, 77, R11-R24. [CrossRef]

225. Brew, K. Structure of human ACE gives new insights into inhibitor binding and design. Trends Pharmacol. Sci. 2003, 24, 391-394. [CrossRef]

226. FitzGerald, R.J.; Murray, B.A.; Walsh, D.J. Hypotensive peptides from milk proteins. J. Nutr. 2004, 134, 980S-988S. [CrossRef] [PubMed]

227. Cheung, H.S.; Wang, F.L.; Ondetti, M.A.; Sabo, E.F.; Cushman, D.W. Binding of peptide substrates and inhibitors of angiotensin-converting enzyme. Importance of the $\mathrm{COOH}$-terminal dipeptide sequence. J. Biol Chem. 1980, 255, 401-407. [PubMed]

228. Moskowitz, D.W. Is "somatic" angiotensin I-converting enzyme a mechanosensor? Diabetes Technol. Ther. 2002, 4, 841-858. [CrossRef] [PubMed]

229. Talero, E.; García-Mauriño, S.; Ávila-Román, J.; Rodríguez-Luna, A.; Alcaide, A.; Motilva, V. Bioactive compounds isolated from microalgae in chronic inflammation and cancer. Mar. Drugs 2015, 13, 6152-6209. [CrossRef]

230. Jellinger, K.A. Recent advances in our understanding of neurodegeneration. J. Neural Transm. (Vienna) 2009, 116, 1111-1162. [CrossRef]

231. Mhatre, M.; Hensley, K. Oxidative Stress and Neuroinflammation in Alzheimer's Disease and Amyotrophic Lateral Sclerosis: From Biology to Therapeutic Strategies. In Oxidative Stress and Neurodegenerative Disorders, 1st ed.; Qureshi, G.A., Parvez, S.H., Eds.; Elsevier: Amsterdam, The Netherlands, 2007; pp. 297-311.

232. Popa-Wagner, A.; Mitran, S.; Sivanesan, S.; Chang, E.; Buga, A.M. ROS and brain diseases: The good, the bad, and the ugly. Oxid. Med. Cell. Longev. 2013, 2013, 14. [CrossRef]

233. Ravipati, A.S.; Zhang, L.; Koyyalamudi, S.R.; Jeong, S.C.; Reddy, N.; Bartlett, J.; Smith, P.T.; Shanmugam, K.; Münch, G.; Wu, M.J.; et al. Antioxidant and anti-inflammatory activities of selected Chinese medicinal plants and their relation with antioxidant content. BMC Complement. Altern. Med. 2012, 12, 173. [CrossRef]

234. Biswas, S.K. Does the interdependence between oxidative stress and inflammation explain the antioxidant paradox? Oxid. Med. Cell Longev. 2016, 2016, 5698931. [CrossRef] 
235. Montero-Lobato, Z.; Vázquez, M.; Navarro, F.; Fuentes, J.; Bermejo, E.; Garbayo, I.; Vílchez, C.; Cuaresma, M. Chemically-Induced Production of Anti-Inflammatory Molecules in Microalgae. Mar. Drugs 2018, 16, 478. [CrossRef]

236. Blagojević, D.; Babić, O.; Rašeta, M.; Šibul, F.; Janjušević, L.; Simeunović, J. Antioxidant activity and phenolic profile in filamentous cyanobacteria: The impact of nitrogen. J. Appl. Phycol. 2018, 30, 2337. [CrossRef]

237. Robertson, R.; Guihéneuf, F.; Bahar, B.; Schmid, M.; Stengel, D.; Fitzgerald, G.; Fitzgerald, G.; Ross, R.; Stanton, C. The anti-inflammatory effect of algae-derived lipid extracts on lipopolysaccharide (LPS)-stimulated human THP-1 macrophages. Mar. Drugs 2015, 13, 5402-5424. [CrossRef]

238. Hussain, T.; Tan, B.; Yin, Y.; Blachier, F.; Tossou, M.C.; Rahu, N. Oxidative stress and inflammation: What polyphenols can do for us? Oxid. Med. Cell Longev. 2016, 2016, 7432797. [CrossRef]

239. Arulselvan, P.; Fard, M.T.; Tan, W.S.; Gothai, S.; Fakurazi, S.; Norhaizan, M.E.; Kumar, S.S. Role of antioxidants and natural products in inflammation. Oxid. Med. Cell Longev. 2016, 2016, 5276130. [CrossRef]

240. Yates, C.M.; Calder, P.C.; Rainger, G. Pharmacology and therapeutics of omega-3 polyunsaturated fatty acids in chronic inflammatory disease. Pharmacol. Ther. 2014, 141, 272-282. [CrossRef]

241. Banskota, A.H.; Gallant, P.; Stefanova, R.; Melanson, R.; O'Leary, S.J. Monogalactosyldiacylglycerols, potent nitric oxide inhibitors from the marine microalga Tetraselmis chuii. Nat. Prod. Res. 2013, 27, 1084-1090. [CrossRef]

242. Banskota, A.H.; Stefanova, R.; Gallant, P.; Osborne, J.A.; Melanson, R.; O’Leary, S.J. Nitric oxide inhibitory activity of monogalactosylmonoacylglycerols from a freshwater microalgae Chlorella sorokiniana. Nat. Prod. Res. 2013, 27, 1028-1031. [CrossRef]

243. Van Beelen, V.A.; Spenkelink, B.; Mooibroek, H.; Sijtsma, L.; Bosch, D.; Rietjens, I.M.C.M.; Alink, G.M. An n-3 PUFA-rich microalgal oil diet protects to a similar extent as a fish oil-rich diet against AOM-induced colonic aberrant crypt foci in F344 rats. Food Chem. Toxicol. 2009, 47, 316-320. [CrossRef]

244. Khan, M.N.; Cho, J.Y.; Lee, M.C.; Kang, J.Y.; Park, N.G.; Fujii, H.; Honh, Y.K. Isolation of two anti-inflammatory and one pro-inflammatory polyunsaturated fatty acids from the brown seaweed Undaria pinnatifida. J. Agric. Food Chem. 2007, 55, 6984-6988. [CrossRef]

245. Vo, T.S.; Kim, J.A.; Wijesekara, I.; Kong, C.S.; Kim, S.K. Potent effect of brown algae (Ishige okamurae) on suppression of allergic inflammation in human basophilic KU812F cells. Food Sci. Biotechnol. 2011, 20, 1227-1234. [CrossRef]

246. Ohgami, K.; Shiratori, K.; Kotake, S.; Nishida, T.; Mizuki, N.; Yazawa, K.; Ohno, S. Effects of astaxanthin on lipopolysaccharide induced inflammation in vitro and in vivo. Investig. Ophthalmol. Vis. Sci. 2003, 44, 2694-2701. [CrossRef]

247. Choi, Y.; Lee, M.K.; Lim, S.Y.; Sung, S.H.; Kim, Y.C. Inhibition of inducible NO synthase, cyclooxygenase-2 and interleukin- $1 \beta$ by torilin is mediated by mitogen-activated protein kinases in microglial BV2 cells. Br. J. Pharmacol. 2009, 156, 933-940. [CrossRef]

248. Rajapakse, N.; Kim, M.M.; Mendis, E.; Kim, S.K. Inhibition of inducible nitric oxide synthase and cyclooxygenase- 2 in lipopolysaccharide-stimulated RAW264.7 cells by carboxybutyrylated glucosamine tales place via down-regulation of mitogen-activated protein kinase-mediated nuclear factor- $\mathrm{kB}$ signaling. Immunology 2008, 123, 348-357. [CrossRef]

249. Speranza, L.; Pesce, M.; Patruno, A.; Franceschelli, S.; de Lutiis, M.A.; Grilli, A.; Felaco, M. Astaxanthin treatment reduced oxidative induced pro-inflammatory cytokines secretion in U937: SHP-1 as a novel biological target. Mar. Drugs 2012, 10, 890-899. [CrossRef]

250. Macedo, R.C.; Bolin, A.P.; Marin, D.P.; Otton, R. Astaxanthin addition improves human neutrophils function: In vitro study. Eur. J. Nutr. 2010, 49, 447-457. [CrossRef]

251. Bennedsen, M.; Wang, X.; Willen, R.; Wadstrom, T.; Andersen, L.P. Treatment of H. pylori infected mice with antioxidant astaxanthin reduces gastric inflammation, bacterial load and modulates cytokine release by splenocytes. Immunol. Lett. 1999, 70, 185-189. [CrossRef]

252. Park, J.S.; Chyun, J.H.; Kim, Y.K.; Line, L.L.; Chew, B.P. Astaxanthin decreased oxidative stress and inflammation and enhanced immune response in humans. Nutr. MeTab. 2010, 7, 18. [CrossRef]

253. Nguyen, V.D. Marine glycans in relationship with probiotic microorganisms to improve human and animal health. In Marine Glycobiology: Principles and Applications; Kim, S.K., Ed.; CRC Press: Boca Raton, FL, USA, 2016. 
254. de Jesus Raposo, M.; de Morais, A.; de Morais, R. Marine polysaccharides from algae with potential biomedical applications. Mar. Drugs 2015, 13, 2967-3028. [CrossRef]

255. Delattre, C.; Pierre, G.; Laroche, C.; Michaud, P. Production, extraction and characterization of microalgal and cyanobacterial exopolysaccharides. Biotechnol. Adv. 2016, 34, 1159-1179. [CrossRef]

256. Matsui, S.M.; Muizzudin, N.; Arad, S.M.; Marenus, K. Sulfated polysaccharides from red microalgae anti-inflammatory properties in vitro and in vivo. Appl. Biochem. Biotechnol. 2003, 104, 13-22. [CrossRef]

257. Albuquerque, I.R.L.; Cordeiro, S.L.; Gomes, D.L.; Dreyfuss, J.L.; Filgueira, L.G.A.; Leite, E.L.; Nader, H.B.; Rocha, H.A.O. Evaluation of anti-nociceptive and anti-inflammatory activities of a heterofucan from Dictyota menstrualis. Mar. Drugs. 2013, 11, 2722-2740. [CrossRef]

258. Kang, S.M.; Kim, K.N.; Lee, S.H.; Ahn, G.; Cha, S.H.; Kim, A.D.; Yang, X.-D.; Kang, M.-C.; Jeon, Y.-J. Anti-inflammatory activity of polysaccharide purified from AMG-assistant extract of Ecklonia cava in LPS-stimulated RAW264.7 macrophages. Carbohydr. Polym. 2011, 85, 80-85. [CrossRef]

259. Li, C.; Gao, Y.; Xing, Y.; Zhu, H.; Shen, J.; Tian, J. Fucoidan, a sulfated polysaccharide from brown algae, against myocardial ischemia-reperfusion injury in rats via regulating the inflammation response. Food Chem. Toxicol. 2011, 49, 2090-2095. [CrossRef]

(C) 2019 by the authors. Licensee MDPI, Basel, Switzerland. This article is an open access article distributed under the terms and conditions of the Creative Commons Attribution (CC BY) license (http://creativecommons.org/licenses/by/4.0/). 